\title{
Chapter 3 \\ Cell Signaling Within Endocrine Glands: Thyroid, Parathyroids and Adrenal Glands
}

\author{
Sofia S. Pereira, Carolina B. Lobato, and Mariana P. Monteiro
}

\begin{abstract}
Despite the fact that there can be argued that no single cell in the human body can be devoid of molecular tools that fit into the broad definition of an endocrine function, some organs are primarily dedicated to hormone secretion and are therefore designated endocrine glands. Under regulation by pituitary gland (reviewed on the previous chapter), three peripheral organs are exclusively devoted to endocrine functions: the thyroid, the parathyroid and the adrenal glands. This Chapter on endocrine system will cover the signaling pathways implied in these three organs, with identification of their particular and shared features.
\end{abstract}

Keywords Endocrine system $\cdot$ Signaling pathways $\cdot$ Thyroid gland $\cdot$ Parathyroid gland $\cdot$ Adrenal gland

\footnotetext{
S. S. Pereira

Instituto de Investigação e Inovação em Saúde (I3S),

Universidade do Porto, Porto, Portugal

e-mail: sspereira@icbas.up.pt

Institute of Molecular Pathology and Immunology,

University of Porto (IPATIMUP), Porto, Portugal

S. S. Pereira · C. B. Lobato · M. P. Monteiro $(\square)$

Endocrine, Cardiovascular and Metabolic Research,

Unit for Multidisciplinary Research in Biomedicine (UMIB),

University of Porto, Porto, Portugal

e-mail: mpmonteiro@icbas.up.pt

C. B. Lobato

e-mail: ccbritolobato@gmail.com

Department of Anatomy, Institute of Biomedical Sciences Abel Salazar (ICBAS),

University of Porto, Porto, Portugal 


\section{Abbreviations}

$\begin{array}{ll}17 \beta H S D 5 & 17 \beta \text {-hydroxysteroid dehydrogenase } \\ 1 \alpha, 25(\mathrm{OH}) 2 \mathrm{D} & 1 \alpha, 25-\text { dihydroxyvitamin D } \\ 2-\mathrm{AG} & 2 \text {-arachidonoylglycerol } \\ {\left[\mathrm{Ca}^{2+}\right]_{\mathrm{i}}} & \text { Intracellular calcium concentration } \\ {\left[\mathrm{Ca}^{2+}\right]_{\mathrm{e}}} & \text { Extracellular ionized calcium concentration } \\ {\left[\left(\mathrm{PO}_{4}\right)^{3-}\right]_{\mathrm{e}}} & \text { Phosphate serum concentration } \\ \text { AA } & \text { Arachidonic acid } \\ \text { AADC } & \text { L-aromatic amino acid decarboxylase } \\ \text { AC } & \text { Adenylate cyclase } \\ \text { Ach } & \text { Acetylcholine } \\ \text { ACTH } & \text { Adrenocorticotropic hormone } \\ \text { ANG I } & \text { Angiotensin I } \\ \text { ANG II } & \text { Angiotensin II } \\ \text { AT1R } & \text { Angiotensin II receptor type 1 } \\ \text { ATF } & \text { Activating transcription factor } \\ \text { ATP } & \text { Adenosine triphosphate } \\ \text { CaMK } & \text { Calmodulin-dependent protein kinases } \\ \text { CaMKII } & \text { Calmodulin-dependent protein kinase II } \\ \text { cAMP } & \text { Cyclic } 3^{\prime} 5^{\prime} \text {-adenosine monophosphate } \\ \text { CaSR } & \text { Calcium-sensing receptor } \\ \text { CREB } & \text { cAMP response element binding } \\ \text { CRH } & \text { Corticotropin-releasing hormone } \\ \text { CT } & \text { Calcitonin } \\ \text { CYB5A } & \text { Cytochrome B5A } \\ \text { CYP11A1 } & \text { Cholesterol side chain cleavage enzyme } \\ \text { CYP11B1 } & 11 \beta \text {-hydroxylase } \\ \text { CYP11B2 } & \text { Aldosterone synthase } \\ \text { CYP17A1 } & 17 \alpha \text {-Hydroxylase } \\ \text { CYP21A2 } & 21 \alpha \text {-hydroxylase } \\ \text { DA } & \text { Dopamine } \\ \text { DAG } & \text { Diacylglycerol } \\ \text { DBH } & \text { Dopamine } \beta \text {-hydroxylase } \\ \text { DHEA } & \text { Dehydroepiandrosterone } \\ \text { DHEA-S } & \text { Dehydroepiandrosterone sulfate } \\ \text { Epi } & \text { Epinephrine } \\ \text { ERK } & \text { Extracellular signal-regulated kinase } \\ \text { FGF23 } & \text { Fibroblast growth factor 23 } \\ \text { GH } & \text { Growth hormone } \\ \text { GR } & \text { Glucocorticoid receptor } \\ \text { Hh } & \text { Hedgehog signaling pathway } \\ \text { HPA } & \text { Hypothalamic-pituitary-adrenal axis } \\ \text { HSL } & \text { Hormone-sensitive lipase } \\ & \\ & \end{array}$


IP3 Inositol 1,4,5-triphosphate

LDL Low-density lipoproteins

LO Lipoxygenase

MAG Monoacylglycerol lipase

MC2R Melanocortin receptor 2

MAPK Mitogen-activated protein kinase

MCT8 Monocarboxylate transporter 8

NCoR Nuclear receptor co-repressor

NE Norepinephrine

NIS Sodium-iodide symporter

NO Nitric oxide

PI3K Phosphoinositide-3-kinase

PIP2 Phosphatidylinositol 4,5-bisphosphate

PNMT Phenylethanolamine N-methyltransferase

PKA Protein kinase A

PKC Protein kinase C

PLA2 Phospholipase A2

PLC Phospholipase C

PLD Phospholipase D

$\left(\mathrm{PO}_{4}\right)^{3-} \quad$ Phosphate

PRL Prolactin

PTH Parathormone

PTHrP Parathyroid hormone-related protein

SF1 Steroidogenic factor 1

Shh Sonic hedgehog

StAR Steroidogenic acute regulatory protein

SULT2A1 Sulfotransferase 2A1

T3 Triiodothyronine

T4 Thyroxine

TG Thyroglobulin

THSR Thyroid-stimulating hormone receptor

TPO Thyroid peroxidase

TRH Thyrotropin-releasing hormone

TRHR1 Thyrotropin-releasing hormone receptor 1

TSH Thyroid-stimulating hormone

TSHR Thyroid-stimulating hormone receptor

VMAT1 Vesicular monoamine transporter 1

VGCC Voltage-gated $\mathrm{Ca}^{2+}$ channels 


\subsection{Introduction}

There can be no argue that there is no single cell in the human body devoid of functionalities that could fit in this broad definition of an endocrine function, some cell types present a specific histological endocrine differentiation and are primarily committed to synthesize and secrete hormones. Endocrine differentiated cells can be found either scattered, isolated or in cell aggregates in organs pertaining to different physiological systems, such as endocrine cells along the gastro-intestinal system which comprise part of the "diffuse endocrine system", or in alternative can be organized in endocrine tissues within organs that are dedicated to the secretion of specific hormones, also known as endocrine glands. Hormones can be classified according to three different molecular classes based on their chemical structure: peptide hormones, which include proteins and polypeptides; steroids, which are lipidderived hormones and amino acid-derived, namely tyrosine derived hormones [1].

The focus of this chapter will be to describe the signaling pathways so far identified in the three peripheral glands of the endocrine system, namely within thyroid, parathyroid and adrenal gland.

\subsection{Thyroid Gland}

The thyroid is an endocrine gland located in the anterior part of the lower neck [2]. The functional unit of the gland is the thyroid follicle that consists of a central core of colloid surrounded by an epithelium with a single layer of follicular cells (Fig. 3.1). In the thyroid gland parenchyma there are two predominant cell types: the epithelial follicular cells, which are the vast majority of thyroid tissue cells [3] and the parafollicular cells, also known as $\mathrm{C}$ cells that reside in the periphery of the follicle $[3,4]$.

\subsubsection{Follicular Cells}

Thyroid follicular cells are the ones responsible for the synthesis and secretion of thyroid hormones thyroxine (T4) and triiodothyronine (T3). The most important regulator of thyroid hormones synthesis is the thyroid-stimulating hormone (TSH) secreted by the anterior pituitary gland under the influence of the hypothalamic thyrotropin-releasing hormone (TRH). TSH is very sensitive to small fluctuations in serum thyroid hormones levels [5]. Besides that, as iodine is a limiting substrate for thyroid hormone synthesis, dietary iodine availability is also an important regulatory factor [6]. 


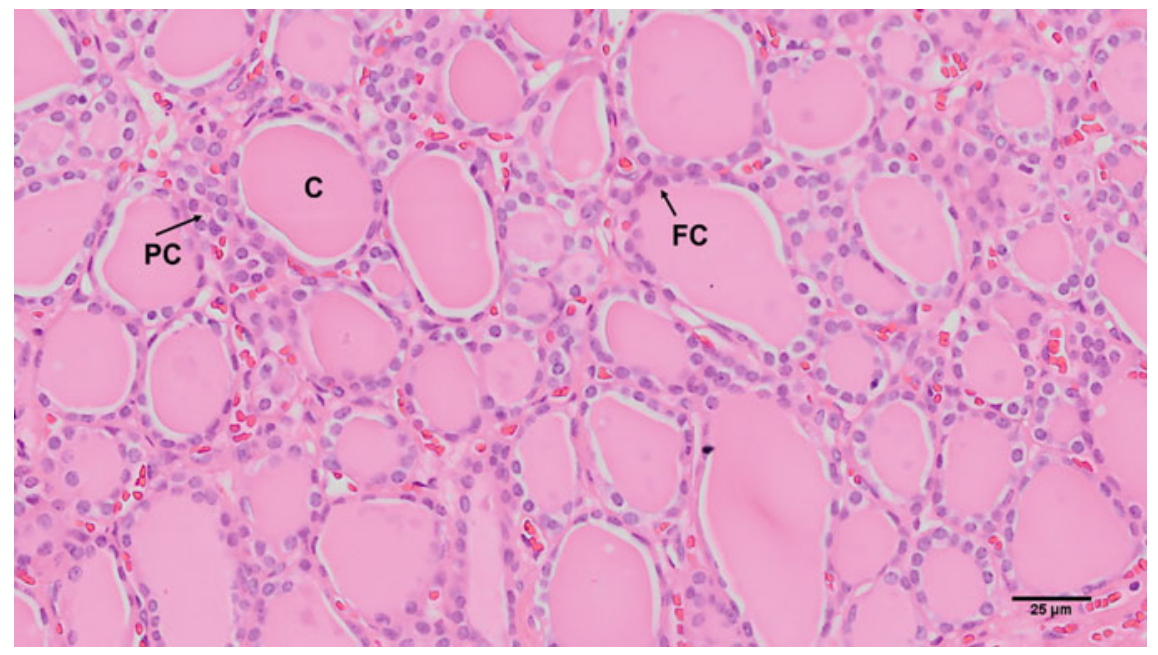

Fig. 3.1 Human thyroid gland stained by hematoxylin and eosin (H\&E) (200x); C-Colloid, FCFollicular cells, PC—Parafollicular cells

\subsubsection{Regulation of Thyroid Hormones Synthesis by TSH}

TSH is the main physiological hormone implicated in thyroid function regulation. TSH acts on the follicular thyroid cell by activating the TSH receptor (TSHR), a member of the glycoprotein G coupled-receptor family (Fig. 3.2) [7]. TSHR is located at the basolateral membrane of thyroid follicular cells and mediates the activation of two regulatory pathways: cyclic $3^{\prime}, 5^{\prime}$-adenosine monophosphate (cAMP) and phospholipase $\mathrm{C}$ (PLC) cascades $[8,9]$. This dual-activation is rendered by the ability of TSHR being capable to interact with all $\mathrm{G} \alpha$ subtypes, in particular with the Gs and Gq subtypes [10,11].

After TSH-mediated receptor activation TSHR couples predominantly to Gs $[12,13]$. Gs activation then leads to cAMP production that binds to the regulatory subunit of protein kinase A (PKA), releasing and activating its catalytic subunit. Activated PKA regulates the iodine uptake and the transcription of genes involved in thyroid hormone production: sodium-iodide symporter (NIS), thyroglobulin (TG) and thyroid peroxidase (TPO) $[4,9,14]$.

In the PLC cascade, the TSHR activation causes the activation of Gq protein that stimulates PLC $[8,9]$. PLC hydrolyzes phosphatidylinositol 4,5-bisphosphate (PIP2) into diacylglycerol (DAG) and inositol 1,4,5-triphosphate (IP3). IP3 binds to its endoplasmic reticulum receptors, which act as channels for the release of the $\mathrm{Ca}^{2+}$ stored in this organelle. Increased intracellular calcium concentration $\left[\mathrm{Ca}^{2+}\right]_{\mathrm{i}}$ is followed by an increase of $\mathrm{Ca}^{2+}$ from the extracellular medium. In thyroid cells, $\mathrm{Ca}^{2+}$ activates calmodulin-dependent protein kinases $(\mathrm{CaMK})$ that regulate the iodide apical efflux, $\mathrm{H}_{2} \mathrm{O}_{2}$ generation through Dual oxidase 2 (DUOX-2) activation, TG iodination and constitutive activation of nitric oxide (NO) synthase [9, 12, 15]. In 


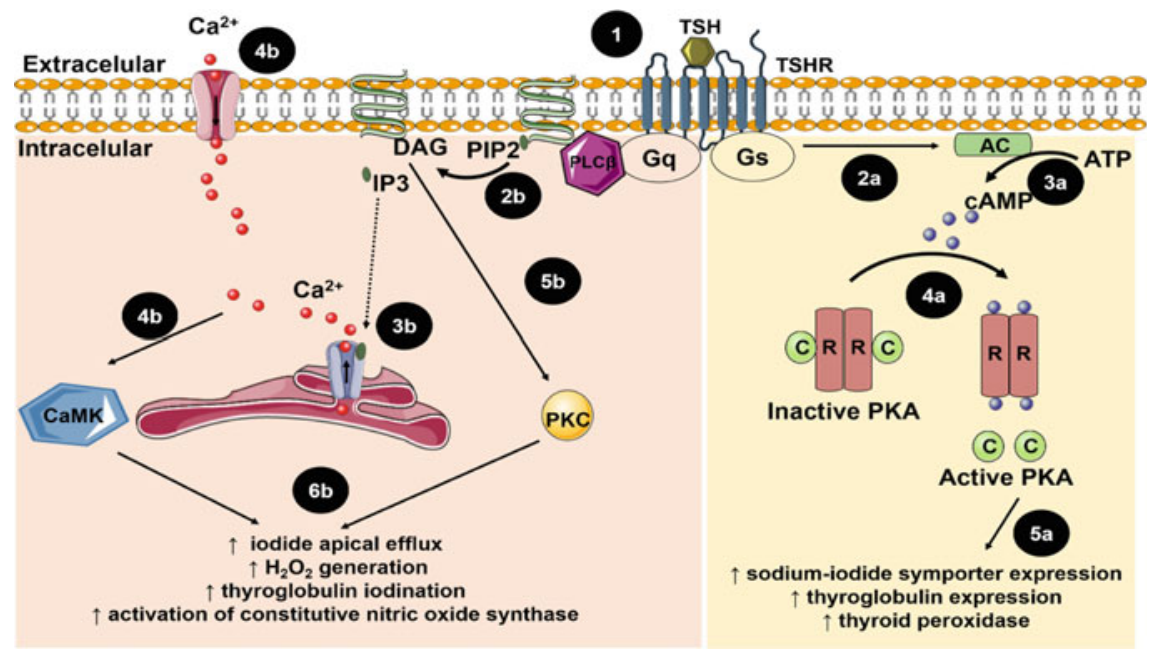

Fig. 3.2 Signaling pathways activated by thyroid stimulating hormone (TSH) in thyroid follicular cells. (1) TSH binds to the thyroid stimulating hormone receptor (THSR), activating two G $\alpha$ protein subtypes: Gs and Gq. These proteins activate two different regulatory pathways: cAMP and phospholipase-C (PLC) pathways, respectively. cAMP pathway: (2a) Gs activates adenylate cyclase (AC); (3a) AC converts adenosine triphosphate (ATP) to cAMP; (4a) cAMP binds to the regulatory subunits $(\mathrm{R})$ of protein kinase A (PKA), releasing and activating the catalytic subunits $(\mathrm{C})$ of this protein (5a) Activated PKA activates transcription of genes involved in the thyroid hormone production: sodium-iodide symporter, thyroglobulin and thyroid peroxidase. PLC pathway: (2b) Gq activation stimulates PLC that hydrolyzes phosphatidylinositol 4,5-bisphosphate (PIP2) into diacylglycerol (DAG) and inositol 1,4,5-triphosphate (IP3); (3b) IP3 binds to its endoplasmic reticulum receptors releasing the $\mathrm{Ca}^{2+}$ stored in this organelle; (4b) Increased intracellular $\mathrm{Ca}^{2+}$ is followed by an increase of $\mathrm{Ca}^{2+}$ from the extracellular medium and calmodulin-dependent protein kinases (CaMK) activation; (5b) DAG activates the protein kinase C (PKC); (6b) PLC pathway, through CaMK and PKC activation, regulate the iodide apical efflux, $\mathrm{H}_{2} \mathrm{O}_{2}$ generation, thyroglobulin iodination and constitutive activation of nitric oxide synthase. Notes Dotted arrows depict particles movement

addition, DAG, the other molecule that results from PIP2 hydrolysis, is responsible for the activation of protein kinase $\mathrm{C}$ (PKC) which in turn activates protein kinase $\mathrm{D}$ (PKD) that enhances iodination and also activates the transcription of genes involved in the thyroid hormone production, such as DUOX-2 [4, 16, 17].

A cross-signaling between PIP2 and cAMP cascades has been reported. The activation of CAMK through the PIP2 cascade inhibits cAMP accumulation and thus the cAMP cascade. Besides that, the PKC activation enhances cAMP response to TSH $[4,18]$. 


\subsubsection{Regulation of Thyroid Hormones Synthesis by Iodine}

Iodine is the main substrate used by thyroid follicular cells for the synthesis of thyroid hormones [6]. The thyroid gland has the capacity to maintain synthesis and secretion of thyroid hormones when iodine availability becomes scarce by shifting the synthesis of hormones from T4 to T3, which synthesis requires less iodine besides being more potent [19].

In contrast, iodide excess decreases the thyroid response to TSH, thus inhibiting the thyroid hormones secretion. This phenomenon, known as the Wolff-Chaikoff effect, was first described in 1948 by Wolff and Chaikoff after the observation that rats exposed to high amounts of iodide, presented decreased levels of organic form of iodide [20]. Although the molecular mechanisms underlying the acute WolffChaikoff effect are not completely understood, some studies reported that iodide is able to inhibit the first steps of both TSH regulatory pathways, cAMP and PLC pathways, inhibiting the downstream effects and thus the thyroid hormones secretion [21-24]. In normal physiological conditions, iodide-mediated thyroid function inhibition is transient and this phenomenon is termed "Wolff-Chaikoff effect adaptation", which can be explained by the downregulation of the NIS and thus inhibition of iodide transport into the thyroid follicular cells [21].

\subsubsection{Synthesis and Secretion of Thyroid Hormones}

Thyroid hormones synthesis requires two precursors: iodide and TG (Fig. 3.3). First step consists in the transport of iodide into the follicular cell, via NIS. NIS activity is dependent on the $\mathrm{Na}^{+}$gradient created by the $\mathrm{Na}^{+} / \mathrm{K}^{+}$-ATPase $[25,26]$. Through the intracellular electrochemical gradient, iodide goes to the apical surface of the cell and is then transported into the colloid mainly through pendrin channels [26, 27]. Iodine is then oxidized by the enzyme TPO in the presence of hydrogen peroxide, which is generated by a NADPH oxidase, the enzyme DUOX2 [28, 29]. In addition, TG, a hormone containing about 120 tyrosine residues is synthesized on ribosomes, glycosylated in the endoplasmic reticulum, translocated to the Golgi apparatus and packaged in secretory vesicles, which is excreted into the colloid by exocytose [30].

In a process that is also catalyzed by TPO, oxidized iodide is then bounded to the tyrosyl residues of TG to form monoiodotyrosine (MIT) or diiodotyrosine (DIT), containing one or two iodine molecules, respectively [31, 32]. MIT and DIT are then combined to form $\mathrm{T} 3$ and $\mathrm{T} 4$, which in turn contain respectively three or four iodine molecules. Colloid, consisting of a reservoir of iodinated TG containing the thyroid hormones is engulfed in vesicles, by pinocytosis and internalized into the follicular cells. Then the vesicles are digested by lysosomes, which generates T4 and T3 to be released into the bloodstream, via monocarboxylate transporter 8 (MCT8) [33]. In contrast, MIT and DIT are retained in the cell and deiodinated by the iodotyrosine dehalogenase 1 . Iodine is then recycled for further thyroid hormone synthesis $[34,35]$. 


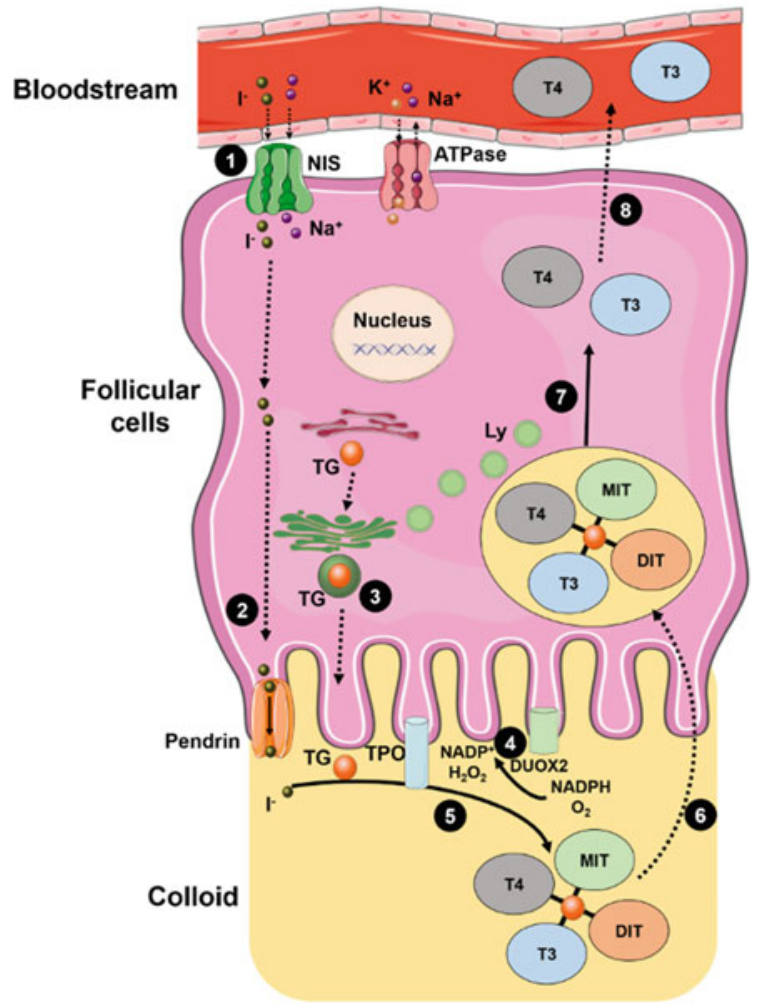

Fig. 3.3 Synthesis and secretion of thyroid hormones by the thyroid follicular cell. (1) Iodide enters the follicular cell, via sodium-iodide symporter (NIS); (2) iodide $\left(\mathrm{I}^{-}\right)$goes to the apical surface of the cell, where it is transported to the colloid mainly through pendrin channels; (3) thyroglobulin (TG) is produced and excreted to the colloid, by exocytose; (4) DUOX2 produce hydrogen peroxide $\left(\mathrm{H}_{2} \mathrm{O}_{2}\right)$; (5) In the presence of $\mathrm{H}_{2} \mathrm{O}_{2}$, thyroid peroxidase (TPO) oxides iodide and attaches it to TG to form monoiodotyrosine (MIT) or diiodotyrosine (DIT), then MIT and DIT combine to form thyroxine (T4) and triiodothyronine (T3); (6) TG complex is then internalized into the follicular cell and form intracellular vesicles; (7) vesicles are digested by lysosomes (Ly), which generates T4 and T3; (8) T3 and T4 are released into the bloodstream. Notes: Dotted arrows depict particles movement

\subsubsection{Parafollicular Cells}

Parafollicular cells are present in the interfollicular connective tissue stroma of the thyroid gland. Contrarily to follicular cells that arise from the endoderm, parafollicular cells derive from the neural crest cells and belong to the neuroendocrine system [2]. Parafollicular cells secrete calcitonin (CT) hormone, which participates in the regulation of $\mathrm{Ca}^{2+}$ homeostasis, although having a minor role [36]. 


\subsubsection{Synthesis and Secretion of Calcitonin}

CT is secreted in response to increased extracellular $\left[\mathrm{Ca}^{2+}\right]_{e}$, through the activation of the calcium-sensing receptor (CaSR), a class $\mathrm{C}$ G-protein-coupled receptor [37-39]. $\mathrm{Ca}^{2+}$-CaSR interaction activates $\mathrm{Gq} / 11$ protein that in turn stimulates PLC. PLC hydrolyzes PIP2 into DAG and IP3. IP3 acutely increases $\left[\mathrm{Ca}^{2+}\right]_{i}$ levels, in a similar process as previously described for the follicular cell, which initiates the processes of CT release from the secretory vesicles into the bloodstream [19, 40]. Besides that, DAG activates PKC that regulates the transcription of key genes for $\mathrm{Ca}^{2+}$ homeostasis, such as CaSR and the gene that encodes CT and CT gene-related peptide $[41,42]$. Contrarily to what occurs with other CaSR responsive cells, such as parathyroid cells, CaSR-mediated CT release from thyroid parafollicular cells seems to occur independently of extracellular signal-regulated kinase (ERK) 1/2 signaling activation and cAMP synthesis suppression [42, 43].

In addition to $\mathrm{Ca}^{2+}$, some gastro-intestinal hormones, including glucagon, gastrin and cholecystokinin were also demonstrated to carry the ability of stimulating CT release from parafollicular cells $[36,44]$.

The physiological effects of CT consist in decreasing blood $\mathrm{Ca}^{2+}$ levels through inhibition of the osteoclast activity in the bones, inhibition of $\mathrm{Ca}^{2+}$ reabsorption by renal tubuli and inhibition of $\mathrm{Ca}^{2+}$ absorption in the intestine [36].

\subsection{Parathyroid Glands}

The human parathyroid glands are most often four ovoid infra centimetric glands located behind each pole of the lateral lobes of the thyroid gland, although anatomical variations in the number and location of the parathyroid glands can frequently occur [2].

The parathyroid tissue is comprised of two functional cell lines, the chief cells and the oxyphil cells. Chief cells are the predominant parathyroid cell type, which are responsible for synthesis and secretion of parathormone (PTH). The function of oxyphil cells remains controversial, despite recent evidence suggesting that these cells result from chief cells deactivation to preserve the PTH secreting potential, in addition to secreting parathyroid hormone-related protein (PTHrP) [45].

\subsubsection{PTH Actions}

PTH is a key player in $\mathrm{Ca}^{2+}$ homeostasis, along with 1 $\alpha, 25$-dihydroxyvitamin $\mathrm{D}\left[1 \alpha, 25(\mathrm{OH})_{2} \mathrm{D}\right]$ and fibroblast growth factor 23 (FGF23). PTH interacts with membrane-specific receptors on target organs, predominantly on kidney and bone to increase circulating $\mathrm{Ca}^{2+}$ levels [46]. 
In the kidney, PTH-mediated $\mathrm{Ca}^{2+}$ reabsorption in the distal convoluted tubule ensures a thigh control over $\mathrm{Ca}^{2+}$ urinary excretion, despite the majority of filtered $\mathrm{Ca}^{2+}$ being reabsorbed along with sodium in the proximal convoluted tubule [47]. Additionally, PTH downregulates sodium-phosphate cotransporters and inhibits sodium-hydrogen antiporter in the proximal convoluted tubule, ultimately leading to decreased reabsorption of phosphate $\left(\left(\mathrm{PO}_{4}\right)^{3-}\right)$ and bicarbonate, respectively [48]. Still in the kidney, PTH activates the 25-hydroxyvitamin D3-1 $\alpha$-hydroxylase gene promoter, the enzyme responsible for the conversion of calcifediol (25hydroxycholecalciferol) into $1 \alpha, 25(\mathrm{OH}) 2 \mathrm{D}$ [49]. In turn, $1 \alpha, 25(\mathrm{OH}) 2 \mathrm{D}$ mediates dietary $\mathrm{Ca}^{2+}$ absorption by intestinal mucosa, with PTH ultimately promoting the alimentary $\mathrm{Ca}^{2+}$ absorption [50].

In the bone, PTH enhances bone turnover, leading to bone mineral matrix reabsorption that results in the release of $\mathrm{Ca}^{2+}$ and $\left(\mathrm{PO}_{4}\right)^{3-}$ into circulation [51], in addition to stimulate new bone formation [52].

\subsubsection{PTH Biosynthesis}

The PTH gene is located on chromosome 11 that when transcribed yields pre-proPTH, the PTH precursor [53]. Pre-pro-PTH consists of 115-amino-acids containing the mature PTH (1-84) sequence along with a 6-amino-acid pro-hormone sequence and a 25-amino-acids signal ("pre") sequence at its N-terminus [54]. Mature PTH is stored in vesicles and granules, which are secreted into the extra-cellular fluid in the presence of low circulating calcium levels [55]. Moreover, PTH is co-stored in granules along with cathepsin B and H [56], capable of degrading PTH into C-terminus PTH fragments that hold no action over PTH/PTHrP receptors, which are selectively secreted under conditions of hypercalcemia rather than mature $\mathrm{PTH}(1-84)$ [55].

\subsubsection{PTH Secretion and Its Regulation}

The most important regulator of PTH secretion is the negative feedback loop elicited by extracellular ionized $\mathrm{Ca}^{2+}$ concentrations $\left(\left[\mathrm{Ca}^{2+}\right]_{\mathrm{e}}\right)[57]$.

In parathyroid cells, an increase in $\left[\mathrm{Ca}^{2+}\right]_{i}$ reduces the fusion of preformed PTH storage vesicles with the cytosolic membrane, thus suppressing PTH secretion, instead of stimulating hormonal secretion as commonly observed in the other endocrine glands [58], although the mechanisms that underlie this phenomena are still poorly characterized [59].

$\left[\mathrm{Ca}^{2+}\right]_{\mathrm{e}}$ binds to the seven-loop transmembrane CaSR on the extracellular membrane of parathyroid chief cells, which is coupled to Gq and Gi proteins [57]. Gq activates PLC that increases the formation of IP3 and DAG from PIP2. In turn, IP3 induces $\mathrm{Ca}^{2+}$ mobilization from intracellular reticular storages, thus increasing 
$\left[\mathrm{Ca}^{2+}\right]_{\mathrm{i}}[60]$. High $\left[\mathrm{Ca}^{2+}\right]_{\mathrm{i}}$ activates $\mathrm{Ca}^{2+}$-dependent $\mathrm{K}^{+}$channels, which lead to cytoplasmic membrane hyperpolarization [61] that ultimately suppresses the fusion of PTH vesicles with the membrane and exocytosis [62]. Moreover, increased $\left[\mathrm{Ca}^{2+}\right]_{\mathrm{i}}$ indirectly activates PLA2 and PLD through PKC activation [63]. DAG is converted by DAG lipase into 2-arachidonoylglycerol (2-AG) that is then hydrolyzed into arachidonic acid (AA) by monoacylglycerol lipase (MAG). AA is also produced by PLA2 that becomes activated in the presence of elevated $\left[\mathrm{Ca}^{2+}\right]_{\mathrm{e}}$ and is ultimately modified by cyclooxygenase, lipoxygenase (LO) and epoxygenase (cytochrome P450) [64]. LO products from AA metabolism are strong inhibitors of PTH secretion when CaSR is activated by high $\left[\mathrm{Ca}^{2+}\right]_{\mathrm{e}}[65,66]$. Moreover, $\mathrm{Gi}$ activation suppresses magnesiummediated adenylate cyclase (AC) activity, thus reducing adenosine triphosphate (ATP) conversion into cAMP [67, 68]. As cAMP is a known mediator for PTH secretion [69], reduction of intracellular cAMP arises as an additional pathway leading to $\mathrm{Ca}^{2+}$-induced PTH secretion suppression (Fig. 3.4) [46].

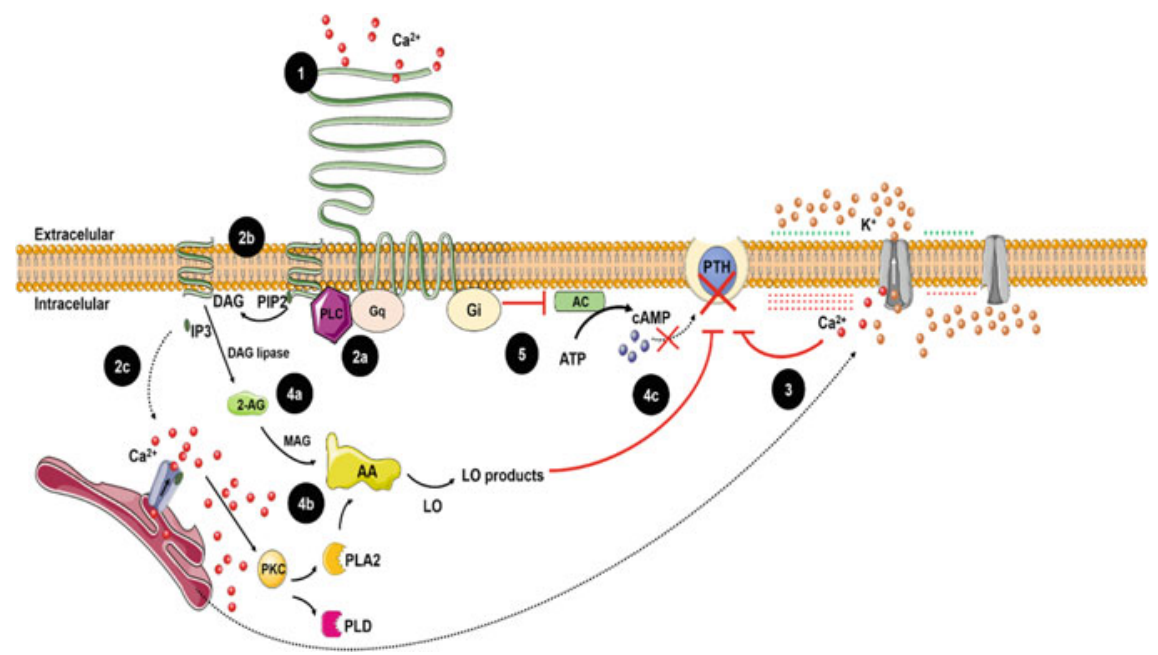

Fig. 3.4 Suppression of PTH secretion by hypercalcemia. (1) Circulating free calcium binds calcium-sensing receptor on parathyroid cell membrane, activating its subunits $\mathrm{Gq}$ and $\mathrm{Gi}$; (2a) Gq activates phospholipase-C (PLC); (2b) PLC hydrolyzes phosphatidylinositol 4,5-bisphosphate (PIP2) into diacylglycerol (DAG) and inositol 1,4,5-triphosphate (IP3); (2c) IP3 induces calcium $\left(\mathrm{Ca}^{2+}\right)$ release from the endoplasmic reticulum. (3) In turn, high intracellular $\mathrm{Ca}^{2+}$ concentrations activate calcium-dependent potassium $\left(\mathrm{K}^{+}\right)$channels, which determines $\mathrm{K}^{+}$outflow and consequently membrane hyperpolarization, suppressing membrane fusion and PTH exocytosis; (4a) Via DAG lipase and monoacylglycerol lipase (MAG), DAG is converted into 2-arachidonoylglycerol (2-AG) and arachidonic acid (AA), respectively; (4b) additionally, via protein kinase C (PKC), increased intracellular $\mathrm{Ca}^{2+}$ levels lead to phospholipases D and A2 activation (PLD and PLA2), also resulting in increased AA formation; (4c) AA is converted by lipoxygenase (LO) and its products also suppress PTH release; (5) lastly, subunit Gi inhibits adenylate cyclase (AC), suppressing cAMP pathway. Together, these pathways suppress PTH secretion and parathyroid cell proliferation, ultimately reducing PTH circulating levels in conditions in hypercalcemia. Notes Red lines represent inhibitory pathways and dotted arrows depict particles movement 
Aside from $\left[\mathrm{Ca}^{2+}\right]_{e}$, other molecules are involved in PTH synthesis and secretion. $1 \alpha, 25(\mathrm{OH})_{2} \mathrm{D}$ extracellular levels contribute to regulate PTH secretion by inhibiting PTH gene transcription and parathyroid proliferation, in a $\mathrm{Ca}^{2+}$-independent fashion $[70,71]$. Additionally, hypermagnesemia is also able to suppress PTH secretion [69, 72], while hypomagnesemia displays more complex effects [73].

Moreover, calmodulin, a $\mathrm{Ca}^{2+}$-binding protein shared by most eukaryotic cells, and calmodulin-dependent protein kinase II (CaMKII) both found in human parathyroid cells, also seem to play a role in regulating calcium homeostasis and PTH secretion [74]. While the role of calmodulin in human parathyroid cells is apparently not directly implied in $\mathrm{Ca}^{2+}$-mediated PTH secretion, levels of active CaMKII decrease in the presence of high $\left[\mathrm{Ca}^{2+}\right]_{\mathrm{e}}$ ultimately leading to decreased PTH secretion [74].

Lastly, FGF23 decreases PTH secretion and PTH mRNA levels probably through mitogen-activated protein kinase (MAPK)/ERK pathway activation, in a feedback loop between bone and parathyroid glands [75].

PTH secretion is stimulated by low circulating calcium levels, which lead to increased levels of mRNA coding pre-pro-PTH probably by increasing mRNA stability [76]. High phosphate serum concentration $\left[\left(\mathrm{PO}_{4}\right)^{3-}\right]_{\mathrm{e}}$, decrease AA levels also leading to PTH secretion [77]. However, even in the presence of high $\left[\left(\mathrm{PO}_{4}\right)^{3-}\right]_{\mathrm{e}}$, PTH secretion is suppressed by high $\left[\mathrm{Ca}^{2+}\right]_{\mathrm{i}}[78]$.

\subsection{Adrenal Gland}

The adrenal glands are a pair of endocrine organs located above the superior pole of each kidney in the retroperitoneal space. Each gland has two distinct parts: an outer region, near the adrenal capsule, designated adrenal cortex that comprises $80 \%$ of the adrenal gland mass, and an inner region, so called adrenal medulla [79]. The adrenal cortex and medulla are separate tissues that have different embryological origin and distinct morphological and functional characteristics [2].

In order to accomplish the physiological roles attributed to the adrenal glands, these rely on a rich arterial blood supply derived from three different branches of the abdominal aorta: inferior phrenic artery, middle adrenal artery and renal artery. The arterial blood enters in the adrenal gland through the capsule and flows centripetally through the adrenal cortex into the medulla [80].

\subsubsection{Adrenal Cortex}

The adrenal cortex is responsible for the adrenal steroid production and it is divided into three distinct morphological layers with different functionality. The layers are the glomerulosa, the fasciculata and the reticularis layers (Fig. 3.5). These three layers present specific enzymatic features that are needed for the production of different steroid hormones [79, 81]. 


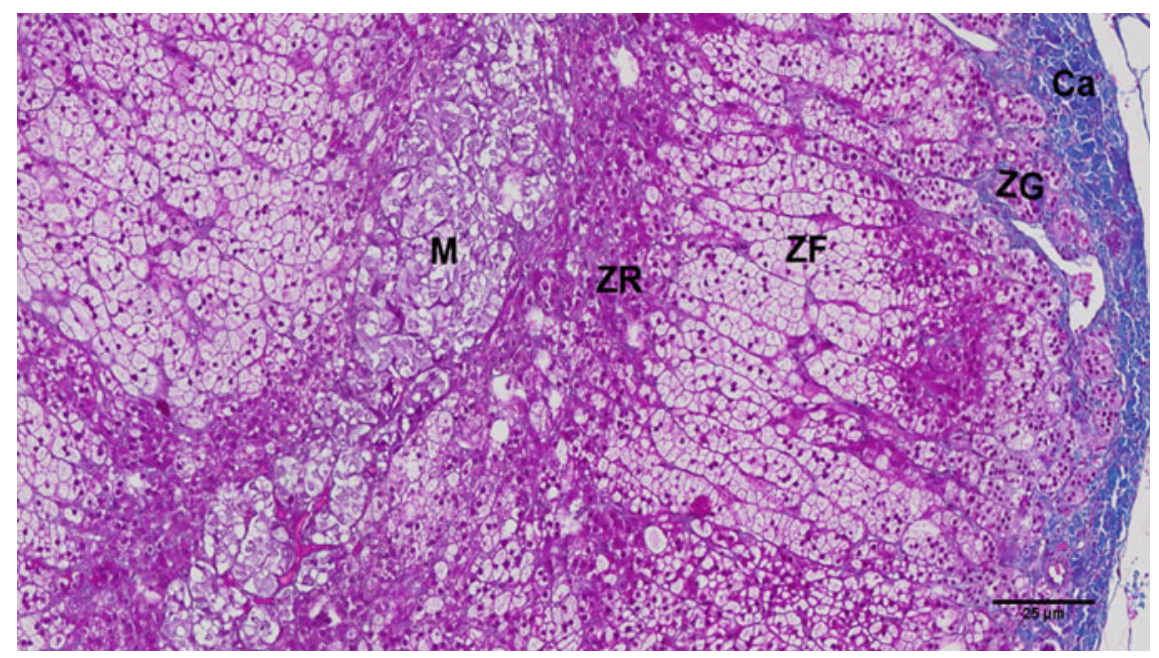

Fig. 3.5 Human adrenal gland stained by Masson tricromium (100x); Ca-Capsule; ZG-Zona glomerulosa; ZF-Zona fasciculata; ZR-Zona reticularis; M-Medulla

\subsubsection{Steroidogenesis}

Adrenocortical steroid hormones are essential in the processes of body homeostasis. Cholesterol is the common precursor of all steroid hormones and is mostly (80\%) obtained from the plasma low-density lipoproteins (LDL) [81, 82]. Besides that, de novo cholesterol synthesis from acetate can also occur in steroidogenic tissues [83]. Cholesterol uptake by steroidogenic cells is performed through receptorsmediated endocytosis and the number of receptors expressed by the cells depend on the presence of stimulus for steroid production [84].

Briefly, after cellular uptake, cytoplasmic cholesterol is transferred from the outer to the inner membrane of the mitochondria, by the steroidogenic acute regulatory protein (StAR) [85]. Once in the mitochondria, cholesterol is hydroxylated twice and cleaved by the cholesterol side chain cleavage enzyme (CYP11A1) to generate pregnenolone [86] (Fig. 3.6). After leaving the mitochondria, pregnenolone is oxidized and isomerized to form progesterone. From this step of the steroidogenic cascade, due to zone-specific enzyme expression, steroidogenesis differs among the different adrenal cortex layers [86, 87]. At the glomerulosa, progesterone is converted into 11-deoxycorticosterone and transferred back into the mitochondria and is successively hydroxylated by aldosterone synthase (CYP11B2) enzyme to originate aldosterone [88]. At the fasciculata, 17 $\alpha$-hydroxylase (CYP17A1) converts pregnenolone into $17 \alpha$-hydroxypregnenolone, which is then oxidized to $17 \alpha-$ hydroxyprogesterone and afterwards hydroxylated by $21 \alpha$-hydroxylase (CYP21A2) to originate 11-deoxycortisol. At this point, 11-deoxycortisol reenters into the mitochondria to be converted by 11 $\beta$-hydroxylase (CYP11B1) into cortisol [87, 89]. 


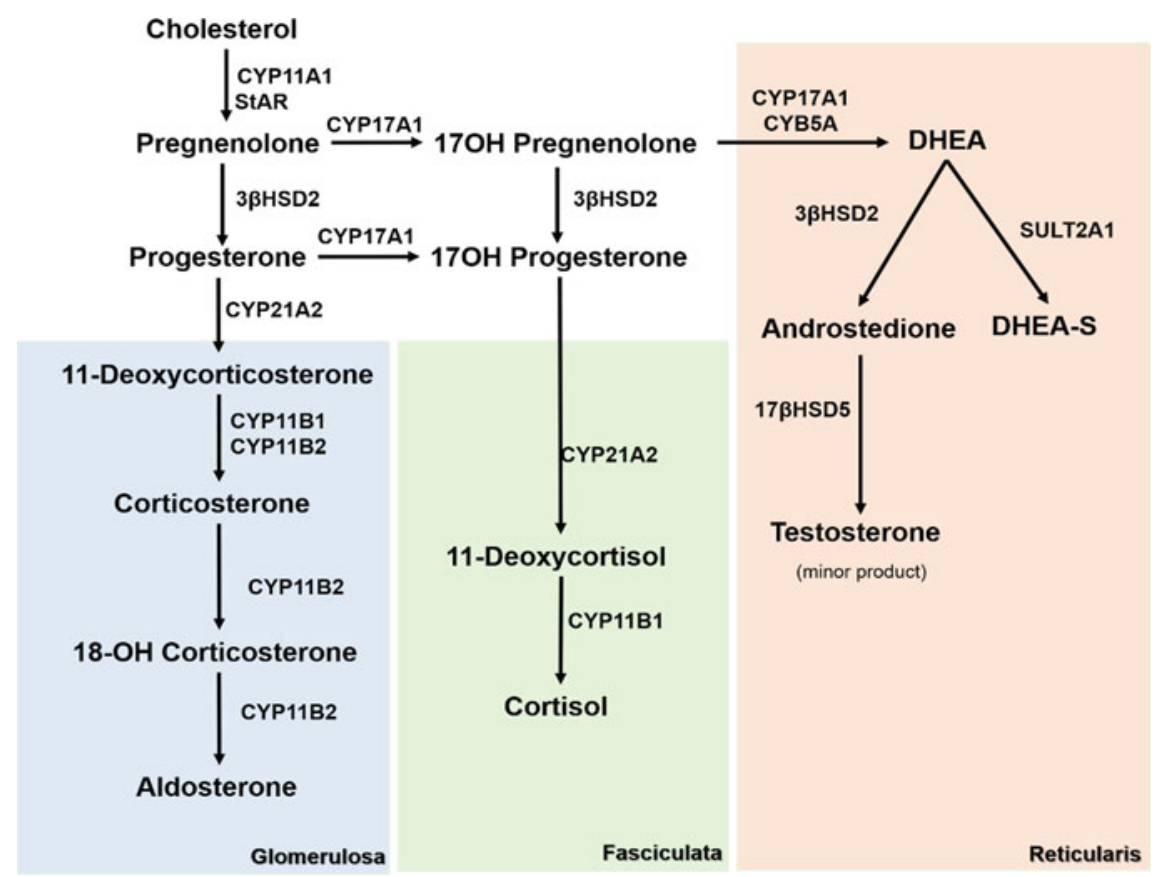

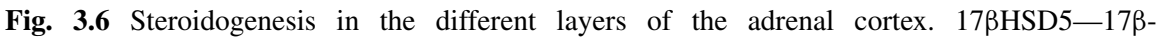
hydroxysteroid dehydrogenase type 5; CYB5A-Cytochrome B5A; CYP11A1-cholesterol side chain cleavage enzyme; CYP11B1-11ß-hydroxylase; CYP11B2-aldosterone synthase; CYP17A1-17 $\alpha$-Hydroxylase; CYP21A2-21 $\alpha$-hydroxylase; dehydroepiandrosterone (DHEA); dehydroepiandrosterone sulfate (DHEA-S); StAR-steroidogenic acute regulatory protein; SULT2A1-Sulfotransferase 2A1

At the zona reticularis, pregnenolone is hydroxylated by CYP17A1 to yield 17hydroxypregnenolone and then into dehydroepiandrosterone (DHEA). Adrenal reticularis layer can also synthesize low levels of testosterone through the action of the enzyme $17 \beta$-hydroxysteroid dehydrogenase type 5 (17ßHSD5) [86, 87, 90].

Due to the lipophilic properties of the steroid hormones, they are not stored in the cells, being only synthesized upon stimulation and immediately secreted [91].

\subsubsection{Adrenocortical Stem Cells}

In early studies, Ingle et al. described the regeneration of the adrenal cortex after adrenal enucleation (removal of the inner content of the adrenal gland) by only leaving the capsule and underlying subcapsular cells intact, suggesting the existence of stem/progenitor cells in the periphery of the adrenal cortex. Furthermore, this finding also corroborated the hypothesis of a centripetal migration and differentiation of the adrenal cortex, previously described [92]. 
The hedgehog signaling pathway $(\mathrm{Hh})$ is a conserved pathway involved in adult tissue maintenance and renewal. Sonic hedgehog (Shh), an Hh family member, is present in a subpopulation of cells organized in clusters under the capsule of the adrenal gland. Lineage-tracing studies revealed that adrenocortical cells are derived from Shh positive cells, suggesting that those cells are the progenitor/stem cells of the adrenal cortex cells. Shh positive cells transduce the signal to the overlying steroidogenic factor 1 (SF1) negative cells present in the adrenal gland capsule triggering the expression of Gli1 molecule. During the adrenal development, Gli1 ${ }^{+}$capsular cells migrate to the adrenal cortex and behave as stem/precursors cells, since these give rise to the $\mathrm{SF} 1^{+} / \mathrm{Shh}^{+}$progenitor cell pool that will lead to differentiated steroidogenic cells $[93,94]$.

\subsubsection{Glomerulosa Layer}

The glomerulosa layer is the outer layer of the adrenal cortex. It is the only layer that expresses CYP11B2 and thereby the single capable of synthetizing mineralocorticoids [95]. The most important and potent mineralocorticoid hormone is the aldosterone. Aldosterone is a key element of the renin-angiotensin-aldosterone system being responsible for regulating sodium homeostasis and thereby helping to control fluid volume and arterial pressure [96, 97].

\section{Aldosterone Synthesis}

The main extracellular stimuli for aldosterone synthesis are angiotensin II (ANG II) and high $\mathrm{K}^{+}$levels. Besides that, adrenocorticotropic hormone (ACTH) is also able to regulate aldosterone synthesis, although it has a minor contribution $[88,98]$.

\section{Renin-Angiotensin-Aldosterone System}

A reduction on the renal perfusion pressure leads to renin synthesis by the kidney juxtaglomerular cells. Renin is an enzyme that cleaves a protein synthesized and secreted by the liver, the angiotensinogen, to form angiotensin I (ANG I) [99]. Then, angiotensin converting enzyme (ACE) converts ANG I into ANG II [100].

In the glomerulosa cells, ANG II binds to the ANG II receptor type 1 (AT1R) which is linked to the G-protein Gq/11 that couples the receptor to its effector PLC (Fig. 3.7). PLC activation leads to the hydrolysis of PIP2 to produce DAG and IP3 $[88,101,102]$. IP3 diffuses into the cytoplasm and binds to its endoplasmic reticulum receptors, which act as channels for the release of the $\mathrm{Ca}^{2+}$ stored in this organelle. It results in a transient increase of the $\mathrm{Ca}^{2+}$ cytoplasmic concentration $[88,98]$. $\left[\mathrm{Ca}^{2+}\right]_{\mathrm{i}}$ leads to the activation of CaMK [103]. The activation of different CaMK were shown to lead to different results: CaMK I is able to increase of the CYP11B2 through the activation of the transcription factors [Activating transcription factor (ATF)/cAMP 


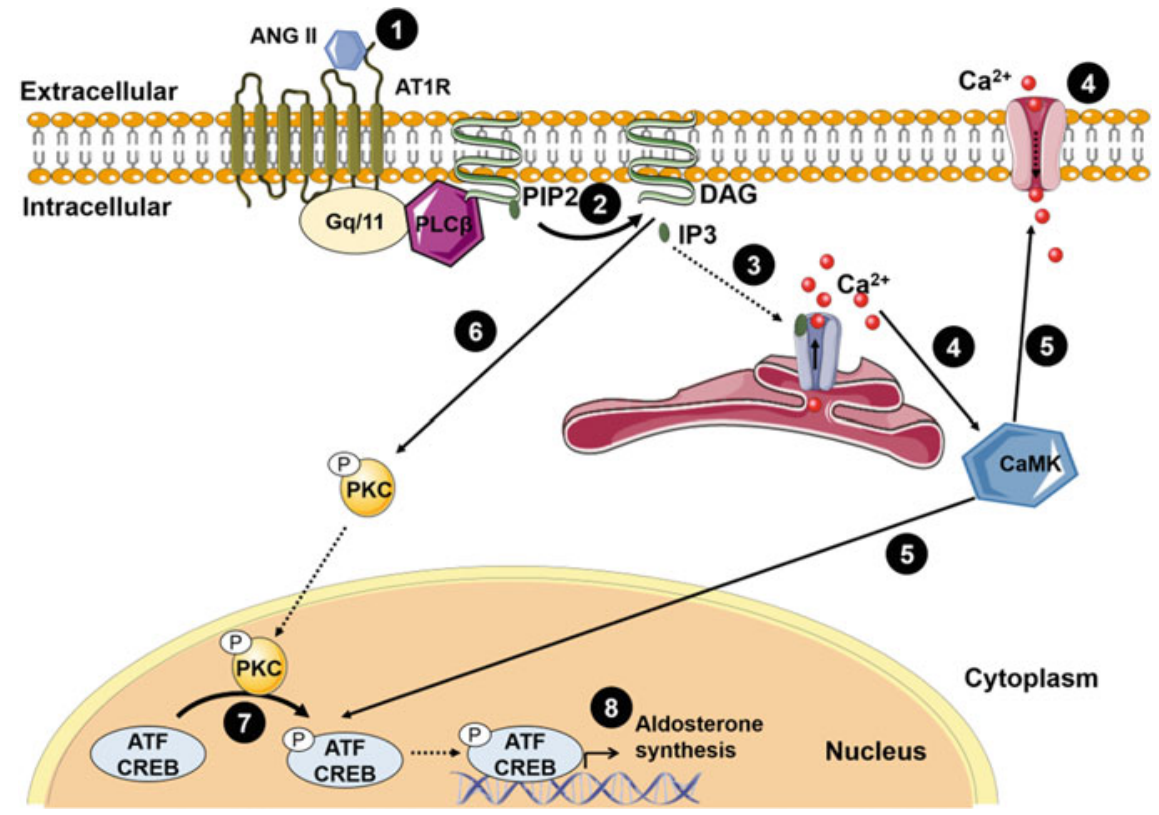

Fig. 3.7 Aldosterone synthesis regulation via angiotensin II (ANG II). (1) ANG II binds to type 1 ANG II receptor (AT1R) which is coupled to phospholipase C (PLC) through the G-protein (Gq/11); (2) PLC- $\beta$ is activated and hydrolyses phosphatidylisitol 4,5-bisphosphate (PIP2) to produce diacylglycerol (DAG) and inositol 1,4,5-triphosphate (IP3); (3) IP3 diffuses into the cytoplasm and binds to its endoplasmic reticulum receptors, which act as channels for the release of the calcium $\left(\mathrm{Ca}^{2+}\right)$; (4) Intracellular $\mathrm{Ca}^{2+}$ activates the calmodulin-dependent protein kinases (CaMK); (5) CaMK activation increases the transcription of the aldosterone synthetize enzyme through the activation of the transcription factors (ATF/CREB) and also shift the voltage of the $\mathrm{Ca}^{2+}$ membrane channels leading to $\mathrm{Ca}^{2+}$ entrance; (6) Simultaneously, DAG activates the protein kinase C (PKC); (7) PKC phosphorylates and activates the transcription factors (ATF/CREB); (8) ATF/CREB activate the transcription of genes involved in aldosterone synthesis. Notes: Dotted arrows depict particles movement

response element binding (CREB)]; and CaMKII, on the other hand, shifts the voltage of the voltage-gated $\mathrm{Ca}^{2+}$ channels (VGCCs) leading to the enhance of $\mathrm{Ca}^{2+}$ influx and then increasing the aldosterone synthesis [88, 98, 103].

In addition, DAG is responsible for the activation of PKC that activates the transcription factors (ATF/CREB) and thus leading to the transcription of StAR and CYP11B2 [88, 104].

ANG II is also able to activate the MAPK signaling pathway, however the mechanisms are not yet completely elucidated [88]. A mechanism already described is that the binding of ANG II to AT1R activates ERK that is able to phosphorylate and activate the enzyme responsible for cleaving the cholesteryl esters to yield the cholesterol [105]. Other evidences, described that ERK can phosphorylate StAR, leading to the transport of cholesterol to the mitochondria [106, 107]. Thus, the mechanisms 
through which MAPK/ERK leads to the aldosterone synthesis are ensuring the availability of cholesterol and its entrance in the mitochondria membrane in order to begin the process of steroidogenesis.

\section{Potassium}

Glomerulosa cells, respond to minor changes in the $\mathrm{K}^{+}$levels with the increase of aldosterone production [108]. High levels of $\mathrm{K}^{+}$lead to depolarization of the glomerulosa cell membrane that lead to the activation of the VGCCs and thus the influx of the $\mathrm{Ca}^{2+}[88,109]$. Increased $\left[\mathrm{Ca}^{2+}\right]_{\mathrm{i}}$ activate $\mathrm{CaMKs}$ and the subsequent pathways already described in the previous section.

In addition, the ability of $\mathrm{K}^{+}$to increase cellular cAMP levels through the $\mathrm{Ca}^{2+}$-sensitive AC was also reported. cAMP activates PKA which then activates the transcription factors (ATF/CREB) and thus leading to the transcription of StAR and CYP11B2 [88, 110].

\section{ACTH}

ACTH binds to melanocortin receptor 2 (MC2R) on the cytoplasmic membrane of glomerulosa cells [111]. Thus, ACTH increases cAMP concentration and activates PKA which phosphorylates and activates hormone-sensitive lipase (HSL) and StAR protein, resulting in the release of cholesterol from lipid droplets and its transportation to the inner mitochondrial membrane [88]. PKA can also activate transcription factors ATF/CREB and then induce the transcription of StAR and CYP11B2 [112]. In addition, PKA stimulates the flow of $\mathrm{Ca}^{2+}$ ions into the glomerulosa cells and thereby increases the production of aldosterone by a mechanism involving CaMKs [113].

\subsubsection{Fasciculate Layer}

Fasciculate layer is the widest zone of the adrenal cortex. It lies under the glomerulosa layer and it is responsible for the synthesis of the glucocorticoids [114]. Cortisol is the most potent glucocorticoid in humans. Moreover, cortisol has a circadian rhythm characterized by a peak in the period before wakening and a gradual decline throughout the day [115]. In addition, cortisol secretion increases acutely in response to stressful stimuli $[116,117]$.

\section{Cortisol Synthesis}

Cortisol secretion is indirectly controlled by the central nervous system. The hypothalamus releases the corticotropin-releasing hormone $(\mathrm{CRH})$ to the long pituitary portal 


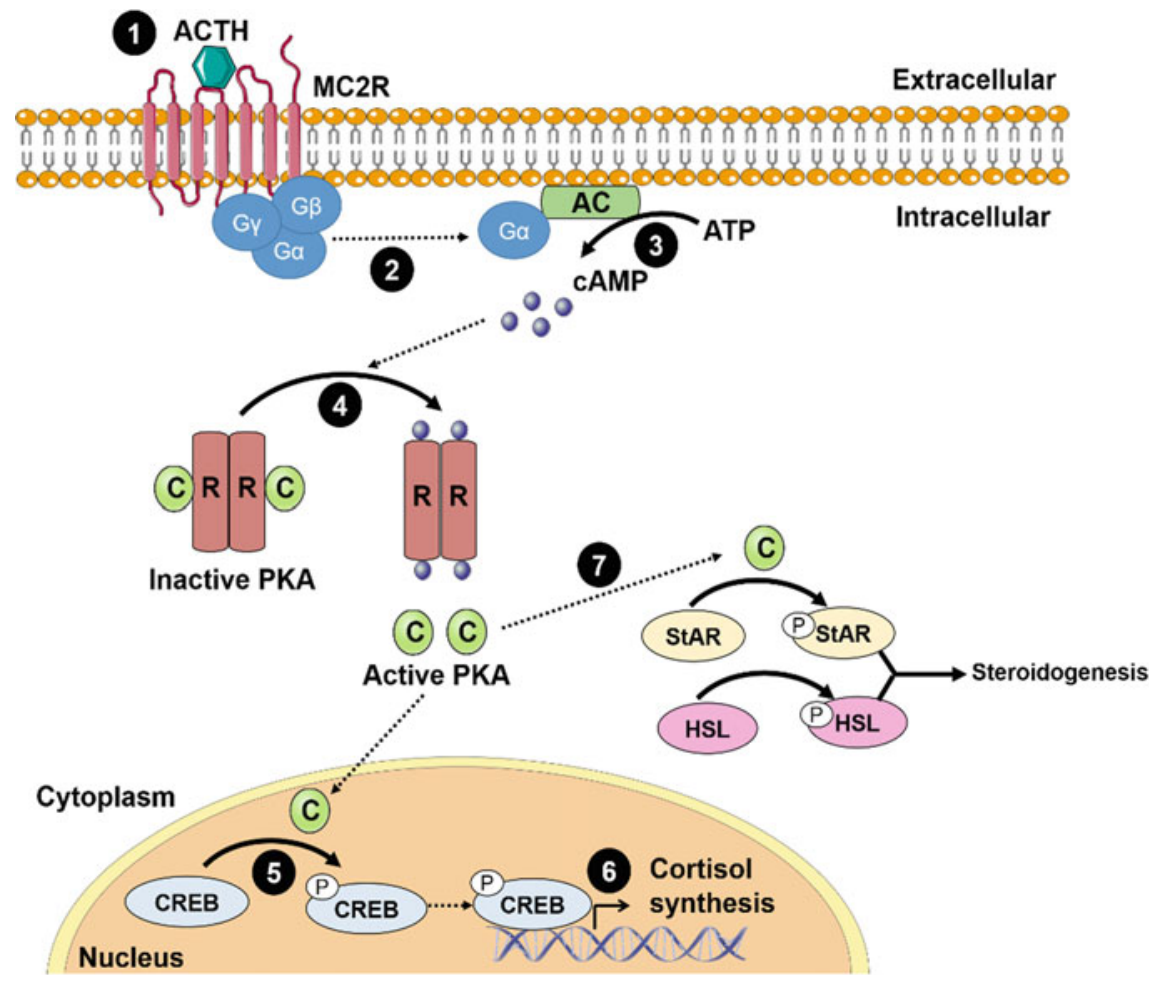

Fig. 3.8 Cortisol synthesis regulation. (1) Adrenocorticotropic hormone (ACTH) binds to the melanocortin receptor 2 (MC2R); (2) G $\alpha$ subunit activate adenylate cyclase (AC); (3) AC converts adenosine triphosphate (ATP) into cyclic $3^{\prime}, 5^{\prime}$-adenosine monophosphate (cAMP); (4) cAMP binds to the regulatory subunits (R) of protein kinase A (PKA), releasing and activating the catalytic subunits (C) of this protein; (5) PKA phosphorylates the cAMP response element binding (CREB) transcription factor; (6) CREB activates the transcription of genes involved in the production of cortisol; (7) Simultaneously, PKA also phosphorylates and activates the hormone-sensitive lipase (HSL) and the steroidogenic acute regulatory protein (StAR), initiating the steroidogenesis. Notes Dotted arrows depict particles movement

veins. $\mathrm{CRH}$ binds to its membrane receptors in the anterior pituitary stimulating the release of ACTH into the blood [117]. ACTH acts on the fasciculate zone cells through the binding to the MC2R and subsequently it induces adrenocortical expansion and cortisol production [111, 118, 119].

Upon ACTH binding, the receptor undergoes conformational changes that activate AC, leading to the conversion of ATP to cAMP (Fig. 3.8) [120]. In turn, cAMP binds to the regulatory subunits of PKA, releasing and activating the catalytic subunits of this protein, which then phosphorylates the CREB transcription factor that leads to increased expression of genes involved in the production of cortisol, such as CYP11B1 [112, 121]. Concomitantly, it also phosphorylates and activates HSL and StAR, initiating the production of cortisol, as previously described [85]. 


\subsubsection{Reticularis Layer}

Reticularis layer is the innermost layer of the adrenal cortex. It is located between the fasciculata layer and the adrenal medulla and it is responsible for the production of the adrenal androgens [114].

\section{Adrenal Androgens Synthesis}

Adrenal androgens synthesis is synchronized with cortisol synthesis in response to ACTH stimulation [122]. The mechanism by which ACTH stimulates androgen synthesis by adrenocortical cells is similar to the mechanism described for cortisol [123]. Like cortisol, plasma levels of DHEA, androstenedione and testosterone exhibit a circadian rhythm. On the contrary, levels of dehydroepiandrosterone sulfate (DHEA-S) do not exhibit a circadian rhythm, since this being a sulfated steroid results in a longer half-life [124, 125].

Other endocrine signals have been proposed as co-regulators of adrenal androgen secretion, such as prolactin (PRL), estrogens, prostaglandins, angiotensin, growth hormone (GH) and gonadotropins [122, 126-128]. However, its impact on androgen secretion is not considered as relevant as ACTH.

\subsubsection{Adrenal Medulla}

The adrenal medulla is the innermost layer of the adrenal gland and is surrounded by the adrenal cortex [129]. The adrenal medulla has an embryonic origin in the neural crest and is composed by chromaffin cells that are structurally and functionally related to postganglionic neurons of the sympathetic nervous system [2]. These cells are responsible for the production of catecholamine: DA, epinephrine (Epi) and NE $[130,131]$.

\subsubsection{Adrenal Catecholamine Synthesis and Secretion}

Like adrenal cortex, adrenal medulla is a key tissue involved in the physiological adaptation to stress [132]. Whenever the central nervous system perceives a stress, two key effector pathways that are activated. These include the hypothalamicpituitary-adrenal axis (HPA), which indirectly stimulates the adrenal medulla to produce catecholamines, and the sympathetic-adrenal axis, which stimulates the adrenal medulla to secrete catecholamines, through a neural mechanism [131-133].

Due to a centripetal blood flow coming from the adrenal cortex, high levels of cortisol pass through the adrenal medulla [80, 134, 135]. As a lipophilic hormone, cortisol is able to easily cross the chromaffin cell membrane to bind the cytoplasmatic glucocorticoid receptor (GR) (Fig. 3.9). Prior to cortisol binding, GR is sequestered 


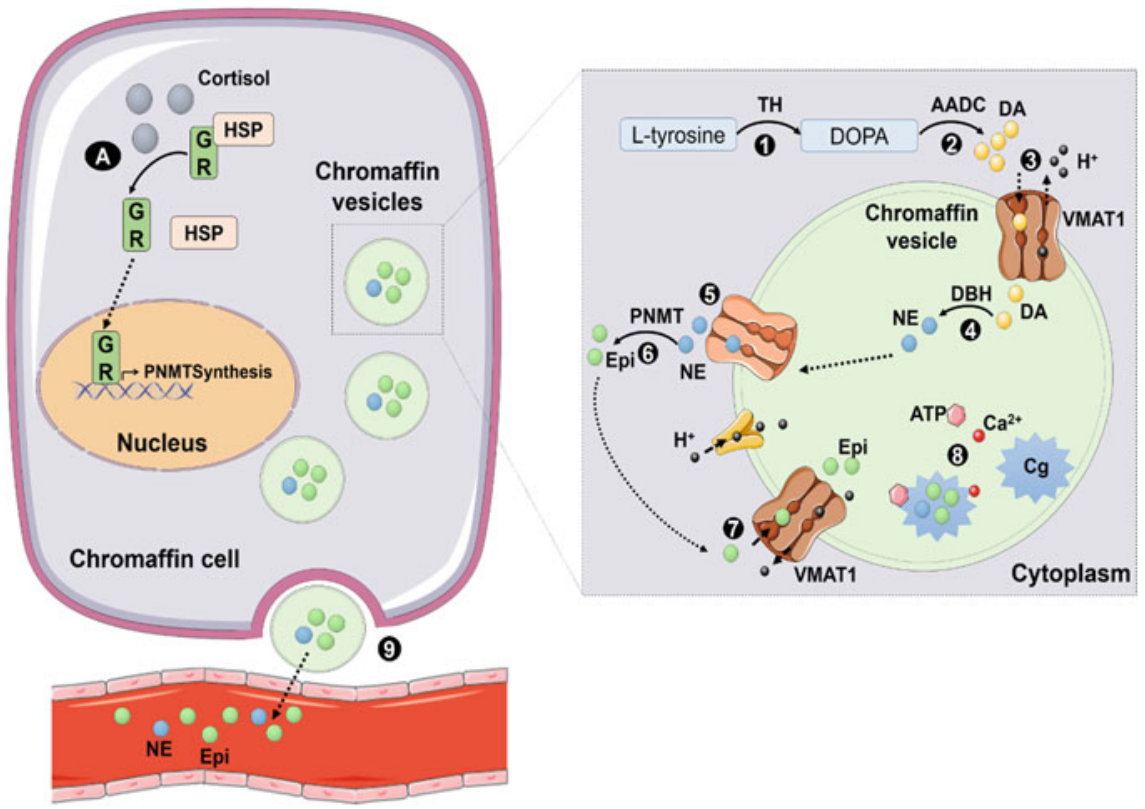

Fig. 3.9 Adrenal catecholamines synthesis and secretion. (A) cortisol crosses the chromaffin cell membrane and binds to the glucocorticoid receptor (GR). GR complex is dissociated and GR goes to the nucleus to bind in glucocorticoid response elements, activating the transcription of phenylethanolamine N-methyltransferase (PNMT); (1) Tyrosine is hydrolyzed by the enzyme tyrosine hydroxylase (TH), producing L-3,4-dihydroxyphenylalanine (L-DOPA); (2) L-DOPA is decarboxylated by the enzyme L-aromatic amino acid decarboxylase (AADC), converting it into DA; (3) DA is then incorporated in chromaffin cell vesicles through the vesicular monoamine transporter 1 (VMAT1); (4) DA is hydroxylated to produce NE by dopamine $\beta$-hydroxylase (DBH); (5) NE can be stored in the vesicles or it can goes to the cytoplasm; (6) in the cytoplasm it is methylated by PNMT to produce Epi; (7) Epi is incorporated in the chromaffin vesicle; (8) in the vesicle NE and Epi are in a complex with chromogranin $(\mathrm{Cg}), \mathrm{Ca}^{2+}$ and adenosine triphosphate (ATP); (9) when stimulated by acetylcholine, the chromaffin cell membrane is depolarized and the catecholamines are released. Notes Dotted arrows depict particles movement

in the cytoplasm as a multiprotein complex [136]. After cortisol binding, the complex is dissociated and GR is translocated into the nucleus where it binds to glucocorticoid response elements (GRE) in the promoter regions of target genes directly or interacts with other transcription factor proteins [133, 136]. Cortisol was found to increase the transcription of genes involved in the biosynthesis of catecholamines, such as phenylethanolamine N-methyltransferase (PNMT) [131, 133, 137].

The biosynthesis of catecholamines begins with the hydroxylation of tyrosine, the catecholamines common precursor, by the enzyme tyrosine hydroxylase (TH), producing L-3,4-dihydroxyphenylalanine (L-DOPA) [133, 138]. After that, L-DOPA is decarboxylated by the enzyme L-aromatic amino acid decarboxylase (AADC), converting it into dopamine (DA) [139]. DA is then incorporated into chromaffin cell vesicles where is hydroxylated to produce NE by dopamine $\beta$-hydroxylase (DBH) 
[140]. NE can be stored in the vesicles until secretion or methylated in the cytoplasm by PNMT to produce Epi [131, 141]. This last step does not occur in the adrenergic neurons as these do not express the PNMT enzyme [131], being specific of the adrenal medulla that is exposed to high levels of cortisol due to the portal nature of the adrenal circulation described above [80, 134, 135].

Catecholamines form a complex with chromogranin, ATP e $\mathrm{Ca}^{2+}$, inside of the chromaffin cell vesicles until being released [137, 142]. Being only produced in the adrenal medulla, Epi is the major secretory product of the adrenal medulla [133, 134].

Opposite to catecholamines synthesis, catecholamines release is mainly mediated by the neuropeptide acetylcholine (ACh) discharge from sympathetic nerve terminals [143]. ACh binds to plasma membrane receptors on chromaffin cells and stimulates $\mathrm{Ca}^{2+}$-mediated depolarization of the cell membrane $[133,144]$. Then the increase of $\left[\mathrm{Ca}^{2+}\right]_{\mathrm{i}}$ levels leads to the release of catecholamines complexed with chromogranin stored in the chromaffin cell vesicles [142, 145].

\subsection{Conclusion}

In this chapter the key signaling pathways involved in the peripheral endocrine organs' maintenance and physiology are described. The knowledge of those pathways is essential for understanding the molecular mechanisms that might lead to endocrine disruption and disease providing important clues into multisystemic impact of endocrine physiology and pathology.

Acknowledgments The work was supported by the Foundation for Science and Technology (PTDC/MEC-ONC/31384/2017). Unit for Multidisciplinary Research in Biomedicine (UMIB) is funded by grants from FCT (UID/Multi/00215/2016 and UID/Multi/00215/2019).

\section{References}

1. Melmed S (2016) Williams textbook of endocrinology. Elsevier Health Sciences

2. Gray H, Standring S (2008) Gray's anatomy: the anatomical basis of clinical practice. Churchill Livingstone

3. Erickson LA (2014) Thyroid histology. In: Atlas of endocrine pathology. Springer, pp 1-11

4. Maenhaut C, Christophe D, Vassart G et al. Ontogeny, anatomy, metabolism and physiology of the thyroid [Updated 2015 Jul 15]. In: Feingold KR, Anawalt B, Boyce A et al (eds) Endotext [Internet]. South Dartmouth (MA): MDText.com, Inc.; 2000

5. Mariotti S, Beck-Peccoz P. Physiology of the hypothalamic-pituitary-thyroid axis [Updated 2016 Aug 14]. In: Feingold KR, Anawalt B, Boyce A et al (eds) Endotext [Internet]. South Dartmouth (MA): MDText.com, Inc.; 2000

6. Chung HR (2014) Iodine and thyroid function. Ann Pediatr Endocrinol Metab 19(1):8-12. https://doi.org/10.6065/apem.2014.19.1.8

7. Davies T, Marians R, Latif R (2002) The TSH receptor reveals itself. J Clin Invest 110(2):161164. https://doi.org/10.1172/JCI16234 
8. Field JB, Ealey PA, Marshall NJ, Cockcroft S (1987) Thyroid-stimulating hormone stimulates increases in inositol phosphates as well as cyclic AMP in the FRTL-5 rat thyroid cell line. Biochem J 247(3):519-524

9. Corvilain B, Laurent E, Lecomte M, Vansande J, Dumont JE (1994) Role of the cyclic adenosine $3^{\prime}, 5^{\prime}$-monophosphate and the phosphatidylinositol- $\mathrm{Ca}^{2+}$ cascades in mediating the effects of thyrotropin and iodide on hormone synthesis and secretion in human thyroid slices. J Clin Endocrinol Metab 79(1):152-159. https://doi.org/10.1210/jcem.79.1.8027219

10. Allgeier A, Offermanns S, Van Sande J, Spicher K, Schultz G, Dumont JE (1994) The human thyrotropin receptor activates G-proteins Gs and Gq/11. J Biol Chem 269(19):13733-13735

11. Laugwitz K-L, Allgeier A, Offermanns S, Spicher K, Van Sande J, Dumont JE, Schultz G (1996) The human thyrotropin receptor: a heptahelical receptor capable of stimulating members of all four $G$ protein families. Proc Natl Acad Sci 93(1):116-120

12. Van Sande J, Dequanter D, Lothaire P, Massart C, Dumont JE, Erneux C (2006) Thyrotropin stimulates the generation of inositol 1,4,5-trisphosphate in human thyroid cells. J Clin Endocrinol Metab 91(3):1099-1107. https://doi.org/10.1210/jc.2005-1324

13. Cleator JH, Ravenell R, Kurtz DT, Hildebrandt JD (2004) A dominant negative Galphas mutant that prevents thyroid-stimulating hormone receptor activation of cAMP production and inositol 1,4,5-trisphosphate turnover: competition by different $\mathrm{G}$ proteins for activation by a common receptor. J Biol Chem 279(35):36601-36607. https://doi.org/10.1074/jbc. M406232200

14. Riedel C, Levy O, Carrasco N (2001) Post-transcriptional regulation of the sodium/iodide symporter by thyrotropin. J Biol Chem 276(24):21458-21463

15. Bekhti-Sari F, Mokhtari-Soulimane N, Merzouk H, Loudjedi L, Ghedouchi S, Guermouche B, Merzouk SA, Berber N (2016) High thyroid stimulating hormone level contributes to nitric oxide and superoxide anion overproduction in women with hypothyroidism. Int J Health Sci Res (IJHSR) 6(3): 118-126

16. Song Y, Driessens N, Costa M, De Deken X, Detours V, Corvilain B, Maenhaut C, Miot F, Van Sande J, Many MC, Dumont JE (2007) Roles of hydrogen peroxide in thyroid physiology and disease. J Clin Endocrinol Metab 92(10):3764-3773. https://doi.org/10.1210/jc.2007-0660

17. Esteves R, Van Sande J, Dumont JE (1992) Nitric oxide as a signal in thyroid. Mol Cell Endocrinol 90(1):R1-R3

18. Dumont JE, Miot F, Erneux C, Couchie D, Cochaux P, Gervy-Decoster C, Van Sande J, Wells JN (1984) Negative regulation of cyclic AMP levels by activation of cyclic nucleotide phosphodiesterases: the example of the dog thyroid. Adv Cycl NuclTide Protein Phosphorylation Res 16:325-336

19. Obregon M-J, del Rey FE, de Escobar GM (2005) The effects of iodine deficiency on thyroid hormone deiodination. Thyroid 15(8):917-929

20. Wolff J, Chaikoff IL (1948) Plasma inorganic iodide as a homeostatic regulator of thyroid function. J Biol Chem 174(2):555-564

21. Leung AM, Braverman LE (2014) Consequences of excess iodine. Nat Rev Endocrinol 10(3):136-142. https://doi.org/10.1038/nrendo.2013.251

22. Wolff J (1989) Excess iodide inhibits the thyroid by multiple mechanisms. In: Control of the thyroid gland. Springer, pp 211-244

23. Van Sande J, Grenier G, Willems C, Dumont JE (1975) Inhibition by iodide of the activation of the thyroid cyclic 3', 5'-AMP system. Endocrinology 96(3):781-786

24. Laurent E, Mockel J, Takazawa K, Erneux C, Dumont JE (1989) Stimulation of generation of inositol phosphates by carbamoylcholine and its inhibition by phorbol esters and iodide in dog thyroid cells. Biochem J 263(3):795-801

25. Dohan O, De la Vieja A, Paroder V, Riedel C, Artani M, Reed M, Ginter CS, Carrasco N (2003) The sodium/iodide Symporter (NIS): characterization, regulation, and medical significance. Endocr Rev 24(1):48-77. https://doi.org/10.1210/er.2001-0029

26. Bizhanova A, Kopp P (2009) The sodium-iodide symporter NIS and pendrin in iodide homeostasis of the thyroid. Endocrinology 150(3):1084-1090. https://doi.org/10.1210/en. 2008-1437 
27. Royaux IE, Suzuki K, Mori A, Katoh R, Everett LA, Kohn LD, Green ED (2000) Pendrin, the protein encoded by the Pendred syndrome gene (PDS), is an apical porter of iodide in the thyroid and is regulated by thyroglobulin in FRTL-5 cells. Endocrinology 141(2):839-845. https://doi.org/10.1210/endo.141.2.7303

28. McLachlan SM, Rapoport B (1992) The molecular biology of thyroid peroxidase: cloning, expression and role as autoantigen in autoimmune thyroid disease. Endocr Rev 13(2):192-206

29. Song Y, Ruf J, Lothaire P, Dequanter D, Andry G, Willemse E, Dumont JE, Van Sande J, De Deken X (2010) Association of duoxes with thyroid peroxidase and its regulation in thyrocytes. J Clin Endocrinol Metab 95(1):375-382. https://doi.org/10.1210/jc.2009-1727

30. Luo Y, Ishido Y, Hiroi N, Ishii N, Suzuki K (2014) The emerging roles of thyroglobulin. Adv Endocrinol 2014:1-7

31. Dunn JT, Dunn AD (1999) The importance of thyroglobulin structure for thyroid hormone biosynthesis. Biochimie 81(5):505-509

32. Maurizis JC, Marriq C, Michelot J, Rolland M, Lissitzky S (1979) Thyroid peroxidase-induced thyroid hormone synthesis in relation to thyroglobulin structure. FEBS Lett 102(1):82-86

33. Rousset B, Selmi S, Bornet H, Bourgeat P, Rabilloud R, Munari-Silem Y (1989) Thyroid hormone residues are released from thyroglobulin with only limited alteration of the thyroglobulin structure. J Biol Chem 264(21):12620-12626

34. Gnidehou S, Caillou B, Talbot M, Ohayon R, Kaniewski J, Noel-Hudson MS, Morand S, Agnangji D, Sezan A, Courtin F, Virion A, Dupuy C (2004) Iodotyrosine dehalogenase 1 (DEHAL1) is a transmembrane protein involved in the recycling of iodide close to the thyroglobulin iodination site. FASEB J: Off Publ Fed Am Soc Exp Biol 18(13):1574-1576. https://doi.org/10.1096/fj.04-2023fje

35. Sorensen MJ, Gauger PG (2015) Thyroid physiology. In: Pasieka JL, Lee JA (eds) Surgical endocrinopathies: clinical management and the founding figures. Springer International Publishing, Cham, pp 3-11. https://doi.org/10.1007/978-3-319-13662-2_1

36. Wimalawansa SJ (2010) Calcitonin: history, physiology, pathophysiology and therapeutic applications. In: Osteoporosis in men, 2nd edn. Elsevier, pp 653-666

37. Freichel M, Zink-Lorenz A, Holloschi A, Hafner M, Flockerzi V, Raue F (1996) Expression of a calcium-sensing receptor in a human medullary thyroid carcinoma cell line and its contribution to calcitonin secretion. Endocrinology 137(9):3842-3848. https://doi.org/10. 1210/endo.137.9.8756555

38. Fudge NJ, Kovacs CS (2004) Physiological studies in heterozygous calcium sensing receptor (CaSR) gene-ablated mice confirm that the CaSR regulates calcitonin release in vivo. BMC physiology 4(1):5

39. Brown EM, MacLeod RJ (2001) Extracellular calcium sensing and extracellular calcium signaling. Physiol Rev 81(1):239-297

40. McGehee DS, Aldersberg M, Liu KP, Hsuing S, Heath MJ, Tamir H (1997) Mechanism of extracellular $\mathrm{Ca}^{2+}$ receptor-stimulated hormone release from sheep thyroid parafollicular cells. J Physiol 502(Pt 1):31-44

41. Suzuki K, Lavaroni S, Mori A, Okajima F, Kimura S, Katoh R, Kawaoi A, Kohn LD (1998) Thyroid transcription factor 1 is calcium modulated and coordinately regulates genes involved in calcium homeostasis in C cells. Mol Cell Biol 18(12):7410-7422. https://doi. org/10.1128/mcb.18.12.7410

42. Leach K, Sexton PM, Christopoulos A, Conigrave AD (2014) Engendering biased signalling from the calcium-sensing receptor for the pharmacotherapy of diverse disorders. Br $\mathrm{J}$ Pharmacol 171(5):1142-1155. https://doi.org/10.1111/bph.12420

43. Cook AE, Mistry SN, Gregory KJ, Furness SG, Sexton PM, Scammells PJ, Conigrave $\mathrm{AD}$, Christopoulos A, Leach K (2015) Biased allosteric modulation at the CaS receptor engendered by structurally diverse calcimimetics. Br J Pharmacol 172(1):185-200. https:// doi.org/10.1111/bph. 12937

44. Erdogan MF, Gursoy A, Kulaksizoglu M (2006) Long-term effects of elevated gastrin levels on calcitonin secretion. J Endocrinol Invest 29(9):771-775. https://doi.org/10.1007/bf03347369 
45. Ritter CS, Haughey BH, Miller B, Brown AJ (2012) Differential gene expression by oxyphil and chief cells of human parathyroid glands. J Clin Endocrinol Metab 97(8):E1499-E1505. https://doi.org/10.1210/jc.2011-3366

46. Habener JF, Rosenblatt M, Potts JT Jr (1984) Parathyroid hormone: biochemical aspects of biosynthesis, secretion, action, and metabolism. Physiol Rev 64(3):985-1053. https://doi. org/10.1152/physrev.1984.64.3.985

47. Friedman PA, Gesek FA (1993) Calcium transport in renal epithelial cells. Am J Physiol 264(2 Pt 2):F181-F198. https://doi.org/10.1152/ajprenal.1993.264.2.F181

48. Massry SG, Coburn JW, Friedler RM, Kurokawa K, Singer FR (1975) Relationship between the kidney and parathyroid hormone. Nephron 15(3-5):197-222. https://doi.org/10.1159/ 000180513

49. Brenza HL, Kimmel-Jehan C, Jehan F, Shinki T, Wakino S, Anazawa H, Suda T, DeLuca HF (1998) Parathyroid hormone activation of the 25-hydroxyvitamin D3-1alpha-hydroxylase gene promoter. Proc Natl Acad Sci USA 95(4):1387-1391

50. Kumar R (1995) Calcium transport in epithelial cells of the intestine and kidney. J Cell Biochem 57(3):392-398. https://doi.org/10.1002/jcb.240570304

51. Kroll MH (2000) Parathyroid hormone temporal effects on bone formation and resorption. Bull Math Biol 62(1):163-188. https://doi.org/10.1006/bulm.1999.0146

52. Lombardi G, Di Somma C, Rubino M, Faggiano A, Vuolo L, Guerra E, Contaldi P, Savastano S, Colao A (2011) The roles of parathyroid hormone in bone remodeling: prospects for novel therapeutics. J Endocrinol Invest 34(7 Suppl):18-22

53. Wiren KM, Freeman MW, Potts JT, Kronenberg HM (1987) Preproparathyroid hormone: a model for analyzing the secretory pathway. Ann N Y Acad Sci 493(1):43-49. https://doi.org/ 10.1111/j.1749-6632.1987.tb27179.x

54. Habener JF, Rosenblatt M, Kemper B, Kronenberg HM, Rich A, Potts Jr JT (1978) Preproparathyroid hormone: amino acid sequence, chemical synthesis, and some biological studies of the precursor region, 75. https://doi.org/10.1073/pnas.75.6.2616

55. D'Amour P, Rakel A, Brossard JH, Rousseau L, Albert C, Cantor T (2006) Acute regulation of circulating parathyroid hormone (PTH) molecular forms by calcium: utility of PTH fragments/PTH(1-84) ratios derived from three generations of PTH assays. J Clin Endocrinol Metab 91(1):283-289. https://doi.org/10.1210/jc.2005-1628

56. Hashizume Y, Waguri S, Watanabe T, Kominami E, Uchiyama Y (1993) Cysteine proteinases in rat parathyroid cells with special reference to their correlation with parathyroid hormone (PTH) in storage granules. J Histochem Cytochem 41(2):273-282. https://doi.org/10.1177/ 41.2.8419463

57. Kumar R, Thompson JR (2011) The regulation of parathyroid hormone secretion and synthesis. J Am Soc Nephrol 22(2):216-224. https://doi.org/10.1681/ASN.2010020186

58. Shoback D, Thatcher J, Leombruno R, Brown E (1983) Effects of extracellular $\mathrm{Ca}^{++}$and $\mathrm{Mg}^{++}$ on cytosolic $\mathrm{Ca}^{++}$and PTH release in dispersed bovine parathyroid cells. Endocrinology 113(1):424-426. https://doi.org/10.1210/endo-113-1-424

59. Brown EM, Hebert SC (1997) Calcium-receptor-regulated parathyroid and renal function. Bone 20(4):303-309

60. Kifor O, Kifor I, Brown EM (1992) Effects of high extracellular calcium concentrations on phosphoinositide turnover and inositol phosphate metabolism in dispersed bovine parathyroid cells. J Bone Miner Res 7(11):1327-1336. https://doi.org/10.1002/jbmr.5650071113

61. Valimaki S, Hoog A, Larsson C, Farnebo LO, Branstrom R (2003) High extracellular Ca2 ${ }^{+}$ hyperpolarizes human parathyroid cells via $\mathrm{Ca}\left(2^{+}\right)$-activated $\mathrm{K}^{+}$channels. J Biol Chem 278(50):49685-49690. https://doi.org/10.1074/jbc.M310595200

62. Oetting M, LeBoff MS, Levy S, Swiston L, Preston J, Chen C, Brown EM (1987) Permeabilization reveals classical stimulus-secretion coupling in bovine parathyroid cells. Endocrinology 121(4):1571-1576. https://doi.org/10.1210/endo-121-4-1571

63. Kifor O, Diaz R, Butters R, Brown EM (1997) The $\mathrm{Ca}^{2+}$-sensing receptor (CaR) activates phospholipases C, A2, and D in bovine parathyroid and CaR-transfected, human embryonic kidney (HEK293) cells. J Bone Miner Res 12(5):715-725. https://doi.org/10.1359/jbmr. 1997.12.5.715 
64. Okada Y, Imendra KG, Miyazaki T, Hotokezaka H, Fujiyama R, Toda K (2011) High extracellular $\mathrm{Ca}^{2+}$ stimulates $\mathrm{Ca}^{2+}$-activated $\mathrm{Cl}$ - currents in frog parathyroid cells through the mediation of arachidonic acid cascade. PLoS One 6(4):e19158. https://doi.org/10.1371/ journal.pone.0019158

65. Bourdeau A, Moutahir M, Souberbielle JC, Bonnet P, Herviaux P, Sachs C, Lieberherr M (1994) Effects of lipoxygenase products of arachidonate metabolism on parathyroid hormone secretion. Endocrinology 135(3):1109-1112. https://doi.org/10.1210/endo.135.3.8070353

66. Canalejo A, Canadillas S, Ballesteros E, Rodriguez M, Almaden Y (2003) Importance of arachidonic acid as a mediator of parathyroid gland response. Kidney Int Suppl 85:S10-S13. https://doi.org/10.1046/j.1523-1755.63.s85.4.x

67. Hofer AM (2005) Another dimension to calcium signaling: a look at extracellular calcium. J Cell Sci 118(Pt 5):855-862. https://doi.org/10.1242/jcs.01705

68. Abe M, Sherwood LM (1972) Regulation of parathyroid hormone secretion by adenyl cyclase. Biochem Biophys Res Commun 48(2):396-401. https://doi.org/10.1016/S0006291X(72)80064-0

69. Rodriguez HJ, Morrison A, Slatopolsky E, Klahr S (1978) Adenylate cyclase of human parathyroid gland. J Clin Endocrinol Metab 47(2):319-325. https://doi.org/10.1210/jcem47-2-319

70. Russell J, Lettieri D, Sherwood LM (1986) Suppression by 1,25(OH)2D3 of transcription of the pre-proparathyroid hormone gene. Endocrinology 119(6):2864-2866. https://doi.org/10. 1210/endo-119-6-2864

71. Kremer R, Bolivar I, Goltzman D, Hendy GN (1989) Influence of calcium and 1,25dihydroxycholecalciferol on proliferation and proto-oncogene expression in primary cultures of bovine parathyroid cells. Endocrinology 125(2):935-941. https://doi.org/10.1210/endo125-2-935

72. Rodriguez-Ortiz ME, Canalejo A, Herencia C, Martinez-Moreno JM, Peralta-Ramirez A, Perez-Martinez P, Navarro-Gonzalez JF, Rodriguez M, Peter M, Gundlach K, Steppan S, Passlick-Deetjen J, Munoz-Castaneda JR, Almaden Y (2014) Magnesium modulates parathyroid hormone secretion and upregulates parathyroid receptor expression at moderately low calcium concentration. Nephrol Dial Transplant 29(2):282-289. https://doi.org/10.1093/ndt/ gft 400

73. Vetter T, Lohse MJ (2002) Magnesium and the parathyroid. Curr Opin Nephrol Hypertens 11(4):403-410

74. Lu M, Berglund E, Larsson C, Hoog A, Farnebo LO, Branstrom R (2011) Calmodulin and calmodulin-dependent protein kinase II inhibit hormone secretion in human parathyroid adenoma. J Endocrinol 208(1):31-39. https://doi.org/10.1677/JOE-10-0123

75. Silver J, Naveh-Many T (2012) FGF23 and the parathyroid. Adv Exp Med Biol 728:92-99. https://doi.org/10.1007/978-1-4614-0887-1_6

76. Nechama M, Uchida T, Mor Yosef-Levi I, Silver J, Naveh-Many T (2009) The peptidyl-prolyl isomerase Pin1 determines parathyroid hormone mRNA levels and stability in rat models of secondary hyperparathyroidism. J Clin Invest 119(10):3102-3114. https://doi.org/10.1172/ JCI39522

77. Almaden Y, Hernandez A, Torregrosa V, Canalejo A, Sabate L, Fernandez Cruz L, Campistol JM, Torres A, Rodriguez M (1998) High phosphate level directly stimulates parathyroid hormone secretion and synthesis by human parathyroid tissue in vitro. J Am Soc Nephrol 9(10): $1845-1852$

78. Almaden Y, Canalejo A, Ballesteros E, Anon G, Canadillas S, Rodriguez M (2002) Regulation of arachidonic acid production by intracellular calcium in parathyroid cells: effect of extracellular phosphate. J Am Soc Nephrol 13(3):693-698

79. Nussey S, Whitehead S (2001) The adrenal gland. Endocrinology: an integrated approach. BIOS Scientific Publishers

80. Merklin RJ (1962) Arterial supply of the suprarenal gland. Anat Rec 144(4):359-371. https:// doi.org/10.1002/ar.1091440407 
81. Payne AH, Hales DB (2004) Overview of steroidogenic enzymes in the pathway from cholesterol to active steroid hormones. Endocr Rev 25(6):947-970

82. Chang TY, Chang CC, Ohgami N, Yamauchi Y (2006) Cholesterol sensing, trafficking, and esterification. Ann Rev Cell Dev Biol 22:129-157. https://doi.org/10.1146/annurev.cellbio. 22.010305.104656

83. Mason JI, Rainey WE (1987) Steroidogenesis in the human fetal adrenal: a role for cholesterol synthesized de novo. J Clin Endocrinol Metab 64(1):140-147

84. Miller WL (2011) Early steps in steroidogenesis: intracellular cholesterol trafficking. Thematic review series: genetics of human lipid diseases. J Lipid Res 52(12):2111-2135. https:// doi.org/10.1194/jlr.R016675

85. Stocco D (2000) The role of the StAR protein in steroidogenesis: challenges for the future. J Endocrinol 164(3):247-253

86. Midzak A, Papadopoulos V (2016) Adrenal mitochondria and steroidogenesis: from individual proteins to functional protein assemblies. Front Endocrinol (Lausanne) 7:106. https:// doi.org/10.3389/fendo.2016.00106

87. Gomez-Sanchez CE, Qi X, Velarde-Miranda C, Plonczynski MW, Parker CR, Rainey W, Satoh F, Maekawa T, Nakamura Y, Sasano H, Gomez-Sanchez EP (2014) Development of monoclonal antibodies against human CYP11B1 and CYP11B2. Mol Cell Endocrinol 383(1-2):111-117. https://doi.org/10.1016/j.mce.2013.11.022

88. Bollag WB (2014) Regulation of aldosterone synthesis and secretion. Compr Physiol 4(3):1017-1055. https://doi.org/10.1002/cphy.c130037

89. Arlt W, Stewart PM (2005) Adrenal corticosteroid biosynthesis, metabolism, and action. Endocrinol Metab Clin 34(2):293-313. https://doi.org/10.1016/j.ecl.2005.01.002

90. Rainey WE, Nakamura Y (2008) Regulation of the adrenal androgen biosynthesis. J Steroid Biochem Mol Biol 108(3):281-286. https://doi.org/10.1016/j.jsbmb.2007.09.015

91. Holst JP, Soldin OP, Guo T, Soldin SJ (2004) Steroid hormones: relevance and measurement in the clinical laboratory. Clin Lab Med 24(1):105-118. https://doi.org/10.1016/j.cll.2004. 01.004

92. Ingle DJ, Higgins GM (1938) Autotransplantation and regeneration of the adrenal gland. Endocrinology 22(4):458-464

93. Lerario AM, Finco I, LaPensee C, Hammer GD (2017) Molecular mechanisms of stem/progenitor cell maintenance in the adrenal cortex. Front Endocrinol (Lausanne) 8:52. https://doi.org/10.3389/fendo.2017.00052

94. Walczak EM, Hammer GD (2015) Regulation of the adrenocortical stem cell niche: implications for disease. Nat Rev Endocrinol 11(1):14

95. Rainey WE (1999) Adrenal zonation: clues from 11beta-hydroxylase and aldosterone synthase. Mol Cell Endocrinol 151(1-2):151-160

96. Laragh JH, Sealey JE (1992) Renin-angiotensin-aldosterone system and the renal regulation of sodium, potassium, and blood pressure homeostasis. In: Handbook of renal physiology. Oxford University Press, New York, pp 1409-1541

97. Atlas SA (2007) The renin-angiotensin aldosterone system: pathophysiological role and pharmacologic inhibition. Journal of managed care pharmacy: JMCP 13 (8 Suppl B):9-20. https://doi.org/10.18553/jmcp.2007.13.s8-b.9

98. Spat A, Hunyady L (2004) Control of aldosterone secretion: a model for convergence in cellular signaling pathways. Physiol Rev 84(2):489-539

99. Castrop H, Höcherl K, Kurtz A, Schweda F, Todorov V, Wagner C (2010) Physiology of kidney renin. Physiol Rev 90(2):607-673

100. Nishiyama A, Kim-Mitsuyama S (2010) New approaches to blockade of the reninangiotensin-aldosterone system: overview of regulation of the renin-angiotensin-aldosterone system. J Pharmacol Sci 113(4):289-291

101. Berridge MJ (1984) Inositol trisphosphate and diacylglycerol as second messengers. Biochem J 220(2):345-360

102. Breault L, Lehoux JG, Gallo-Payet N (1996) Angiotensin II receptors in the human adrenal gland. Endocr Res 22(4):355-361 
103. Barrett PQ, Guagliardo NA, Klein PM, Hu C, Breault DT, Beenhakker MP (2016) Role of voltage-gated calcium channels in the regulation of aldosterone production from zona glomerulosa cells of the adrenal cortex. J Physiol 594(20):5851-5860. https://doi.org/10. 1113/jp271896

104. Rasmussen H, Isales CM, Calle R, Throckmorton D, Anderson M, Gasalla-Herraiz J, McCarthy R (1995) Diacylglycerol production, $\mathrm{Ca}^{2+}$ influx, and protein kinase $\mathrm{C}$ activation in sustained cellular responses. Endocr Rev 16(5):649-681. https://doi.org/10.1210/edrv-165-649

105. Cherradi N, Pardo B, Greenberg AS, Kraemer FB, Capponi AM (2003) Angiotensin II activates cholesterol ester hydrolase in bovine adrenal glomerulosa cells through phosphorylation mediated by p42/p44 mitogen-activated protein kinase. Endocrinology 144(11):4905-4915. https://doi.org/10.1210/en.2003-0325

106. Gyles SL, Burns CJ, Whitehouse BJ, Sugden D, Marsh PJ, Persaud SJ, Jones PM (2001) ERKs regulate cyclic AMP-induced steroid synthesis through transcription of the steroidogenic acute regulatory (StAR) gene. J Biol Chem 276(37):34888-34895.

107. Poderoso C, Maloberti P, Duarte A, Neuman I, Paz C, Maciel FC, Podesta EJ (2009) Hormonal activation of a kinase cascade localized at the mitochondria is required for StAR protein activity. Mol Cell Endocrinol 300(1):37-42

108. Williams GH (2005) Aldosterone biosynthesis, regulation, and classical mechanism of action. Heart Fail Rev 10(1):7-13

109. Bollag WB, Barrett PQ, Isales CM, Liscovitch M, Rasmussen H (1992) Signal transduction mechanisms involved in carbachol-induced aldosterone secretion from bovine adrenal glomerulosa cells. Mol Cell Endocrinol 86(1-2):93-101

110. Borland G, Smith BO, Yarwood SJ (2009) EPAC proteins transduce diverse cellular actions of cAMP. Br J Pharmacol 158(1):70-86

111. Abdel-Malek ZA (2001) Melanocortin receptors: their functions and regulation by physiological agonists and antagonists. Cell Mol Life Sci CMLS 58(3):434-441. https://doi.org/10. 1007/p100000868

112. Simpson ER, Waterman MR (1988) Regulation of the synthesis of steroidogenic enzymes in adrenal cortical cells by ACTH. Ann Rev Physiol 50(1):427-440

113. Kojima I, Kojima K, Rasmussen H (1985) Role of calcium and cAMP in the action of adrenocorticotropin on aldosterone secretion. J Biol Chem 260(7):4248-4256

114. Lowe JS, Anderson PG (2015) Chapter 14-Endocrine system. In: Lowe JS, Anderson PG (eds) Stevens \& Lowe's human histology, 4th edn. Mosby, Philadelphia, pp 263-285. https:// doi.org/10.1016/B978-0-7234-3502-0.00014-0

115. Chung S, Son GH (1812) Kim K (2011) Circadian rhythm of adrenal glucocorticoid: its regulation and clinical implications. Biochem Biophys Acta 5:581-591. https://doi.org/10. 1016/j.bbadis.2011.02.003

116. Dallman MF (1993) Stress update Adaptation of the hypothalamic-pituitary-adrenal axis to chronic stress. Trends Eendocrinol Metab: TEM 4(2):62-69

117. Aguilera G (2011) HPA axis responsiveness to stress: implications for healthy aging. Exp Gerontol 46(2-3):90-95. https://doi.org/10.1016/j.exger.2010.08.023

118. Enyeart JJ (2005) Biochemical and ionic signaling mechanisms for ACTH-stimulated cortisol production. Vitam Horm 70:265-279

119. Penny MK, Finco I, Hammer GD (2017) Cell signaling pathways in the adrenal cortex: links to stem/progenitor biology and neoplasia. Mol Cell Endocrinol 445:42-54

120. Mn C, Guillon G, Payet MD, Gallo-Payet N (2001) Expression and regulation of adenylyl cyclase isoforms in the human adrenal gland. J Clin Endocrinol Metab 86(9):4495-4503

121. Mayr B, Montminy M (2001) Transcriptional regulation by the phosphorylation-dependent factor CREB. Nat Rev Mol Cell Biol 2(8):599

122. Parker LN (1991) Control of adrenal androgen secretion. Endocrinol Metab Clin North Am 20(2):401-421

123. Longcope C (1986) 1 Adrenal and gonadal androgen secretion in normal females. Best Pract Res Clin Endocrinol Metab 15(2):213-228 
124. Rosenfeld RS, Rosenberg BJ, Fukushima DK, Hellman L (1975) 24-hour secretory pattern of dehydroisoandrosterone and dehydroisoandrosterone sulfate. J Clin Endocrinol Metab 40(5):850-855. https://doi.org/10.1210/jcem-40-5-850

125. Feuillan P, Pang S, Schurmeyer T, Avgerinos PC, Chrousos GP (1988) The hypothalamicpituitary-adrenal axis in partial (late-onset) 21-hydroxylase deficiency. J Clin Endocrinol Metab 67(1):154-160. https://doi.org/10.1210/jcem-67-1-154

126. Odell WD, Parker LN (1984) Control of adrenal androgen production. Endocr Res 10(3-4):617-630

127. Parker LN, Lifrak ET, Kawahara CK, Geduld SI, Kozbur XM (1983) Angiotensin II potentiates ACTH-stimulated adrenal androgen secretion. J Steroid Biochem 18(2):205-208

128. Wathen NC, Perry L, Hodgkinson S, Chard T (1985) The relationship between prolactin, dehydroepiandrosterone sulphate and testosterone in normally menstruating females. Acta Endocrinol 109(2):173-175

129. Lowe JS, Anderson PG (2014) Stevens \& Lowe's human histology e-book: with STUDENT CONSULT Online Access. Elsevier Health Sciences

130. Pohorecky LA, Wurtman RJ (1971) Adrenocortical control of epinephrine synthesis. Pharmacol Rev 23(1):1-35

131. Wong DL (2006) Epinephrine biosynthesis: hormonal and neural control during stress. Cell Mol Neurobiol 26(4-6):891-900. https://doi.org/10.1007/s10571-006-9056-6

132. Axelrod J, Reisine TD (1984) Stress hormones: their interaction and regulation. Science (New York, NY) 224(4648):452-459

133. Byrne CJ, Khurana S, Kumar A, Tai TC (2018) Inflammatory signaling in hypertension: regulation of adrenal catecholamine biosynthesis. Front Endocrinol 9(343). https://doi.org/ 10.3389/fendo.2018.00343

134. Wurtman RJ (2002) Stress and the adrenocortical control of epinephrine synthesis. Metab-Clin Experimental 51(6):11-14

135. Valenta LJ, Elias AN, Eisenberg H (1986) ACTH stimulation of adrenal epinephrine and norepinephrine release. Horm Res 23(1):16-20. https://doi.org/10.1159/000180283

136. Nicolaides NC, Galata Z, Kino T, Chrousos GP, Charmandari E (2010) The human glucocorticoid receptor: molecular basis of biologic function. Steroids 75(1):1-12

137. Perlman RL, Chalfie M (1977) Catecholamine release from the adrenal medulla. Clin Endocrinol Metab 6(3):551-576

138. Nagatsu T, Levitt M, Udenfriend S (1964) Tyrosine hydroxylase the initial step in norepinephrine biosynthesis. J Biol Chem 239(9):2910-2917

139. Christenson JG, Dairman W, Udenfriend S (1972) On the identity of DOPA decarboxylase and 5-hydroxytryptophan decarboxylase. Proc Natl Acad Sci 69(2):343-347

140. Weinshilboum R, Axelrod J (1971) Serum dopamine-beta-hydroxylase activity. Circ Res 28(3):307-315

141. Axelrod J (1962) Purification and properties of phenylethanolamine-N-methyl transferase. J Biol Chem 237(5):1657-1660

142. O'Connor DT, Frigon RP (1984) Chromogranin A, the major catecholamine storage vesicle soluble protein. Multiple size forms, subcellular storage, and regional distribution in chromaffin and nervous tissue elucidated by radioimmunoassay. J Biol Chem 259(5):3237-3247

143. Kvetnansky R, Sabban EL, Palkovits M (2009) Catecholaminergic systems in stress: structural and molecular genetic approaches. Physiol Rev 89(2):535-606

144. Brandt B, Hagiwara S, Kidokoro Y, Miyazaki S (1976) Action potentials in the rat chromaffin cell and effects of acetylcholine. J Physiol 263(3):417-439

145. Douglas W, Rubin R (1963) The mechanism of catecholamine release from the adrenal medulla and the role of calcium in stimulus—secretion coupling. J Physiol 167(2):288-310 
Open Access This chapter is distributed under the terms of the Creative Commons Attribution 4.0 International License (http://creativecommons.org/licenses/by/4.0/), which permits use, duplication, adaptation, distribution and reproduction in any medium or format, as long as you give appropriate credit to the original author(s) and the source, a link is provided to the Creative Commons license and any changes made are indicated.

The images or other third party material in this chapter are included in the work's Creative Commons license, unless indicated otherwise in the credit line; if such material is not included in the work's Creative Commons license and the respective action is not permitted by statutory regulation, users will need to obtain permission from the license holder to duplicate, adapt or reproduce the material.

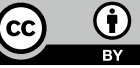

